\title{
O primeiro grande antagonismo entre PSDB e PT
}

\author{
Felipe Corral de Freitas ${ }^{1}$ (D)
}

\begin{abstract}
O objetivo deste artigo consiste em demonstrar a construção antagônica entre os discursos produzidos pelas candidaturas de PSDB e PT realizados durante o Horário Gratuito de Propaganda Eleitoral (HGPE) veiculados pela televisão na eleição presidencial de 1994, que acabou colocando o Plano Real como o ponto nodal desse conflito. A partir disso, percebemos que a dimensão do antagonismo identificada nesse espaço de conflito permite aos eleitores um maior acesso informativo sobre as candidaturas em disputa pela presidência da República, visto seu caráter desconstrutivista. Por isso, o retorno ao passado se justifica por dois principais motivos: a) esse momento pode ser lido como sendo o primeiro grande antagonismo entre os partidos PSDB e PT; e b) pouca ou nenhuma atenção foi dada pelos estudos que envolvem o HGPE à dimensão antagônica, o que pode iluminar mais um dos aspectos referentes à decisão do voto por parte do eleitor. Para isso, serão utilizados os aspectos teóricos e metodológicos da teoria do discurso de Laclau e Mouffe, enfatizando os conceitos de discurso e antagonismo, imprescindíveis para a captura dos sentidos discursivos que aqui são demonstrados. Concluímos, portanto, que a eleição de 1994 marcou o primeiro grande antagonismo entre PSDB e PT.
\end{abstract}

Palavras-chave: HGPE; antagonismo; teoria do discurso; PSDB; PT

\section{Introdução}

No Brasil, após o período ditatorial, momento que pode ser considerado como o primeiro na elaboração de uma legítima agenda no campo de comunicação e política (Rubim e Azevedo, 1998), muitos estudos tratavam da relação entre mídia e política, bem como dos efeitos dessa relação nos programas partidários veiculados durante o Horário Gratuito de Propaganda Eleitoral (doravante HGPE). Os estudos pioneiros nessa nova fase podem ser divididos entre os que buscavam analisar a campanha presidencial de 1989 (Rubim, 1989; Fausto Neto, 1990; Lima, 1990) e os que tratavam do impeachment de Collor (Albuquerque, 1993; Weber, 1993; Fausto Neto, 1994, 1995).

Ampliando esse contexto inicial, diversos estudos sobre campanhas presidenciais, com o HGPE como parte do objeto de estudo, buscavam apresentar as estratégias discursivas dos candidatos (Silva, 2004; Almeida, 2008; Machado, 2009; Massuchin et al., 2016), a construção da imagem partidária (Albuquerque e Dias, 2002; Dias, 2013), o efeito da propaganda eleitoral na intenção de voto (Figueiredo et al., 2000; Figueiredo e Aldé,

\footnotetext{
1 Universidade de Brasília - Instituto de Ciência Política (Ipol), Brasília (DF), Brasil.

E-mail: <felipecorrall@gmail.com>.
} 
2003; Figueiredo, 2007) e a construção da propaganda negativa em relação aos adversários (Rubim, 2004; Lourenço, 2009; Borba, 2015; Borba, Veiga e Martins, 2015). Ainda nesse campo, outro estudo de referência abordava a relação entre propaganda eleitoral, televisão e meios de informação (Albuquerque, 1995).

Num outro viés analítico, os estudos que tratavam mais especificamente sobre mídia e política desenvolviam um debate sobre o papel dos meios de comunicação na formatação dos programas veiculados durante o HGPE e de sua interferência no debate produzido pelas candidaturas, além de sua capacidade de agendar o debate público e interferir de forma significativa numa eleição (Rubim, 1993; Lattman-Weltman, Carneiro e Ramos, 1994; Albuquerque, 1996; Miguel, 1999, 2000, 2002, 2003, 2004a, 2004b; Aruguete, 2005; Cervi, Massuchin e Tavares, 2012; Biroli e Miguel, 2013). Tais perspectivas, respeitando suas diferenças, mas buscando enaltecer um aspecto de semelhança, ajudam a demonstrar a complexidade que envolve os estudos de mídia e política e do HGPE, bem como a interferência produzida na formação da vontade do eleitor.

Por mais que a atitude da grande mídia afete de forma diferente o conteúdo apresentado durante o HGPE pelas candidaturas, e em muitos casos "coordene" a própria eleição (Lattman-Weltman, Carneiro e Ramos, 1994), partimos do entendimento de que o HGPE, em se tratando de uma eleição ao cargo majoritário, possibilita um "debate" mais direto com o eleitor - buscando construir informações sem a "intermediação direta" dos programas jornalísticos -, além de abrir um espaço institucional em que as propostas de uma candidatura possam desconstruir as propostas de outra, bem como as informações passadas pelos grandes meios de comunicação sobre as candidaturas em disputa. Desse modo, o HGPE consegue intervir e contrapor a "vontade" da grande mídia e sua "preferência" por algum candidato e/ou candidatura, como nas eleições de Luiz Inácio Lula da Silva (doravante Lula) e Dilma Rousseff, ambos do PT (Machado, 2009; Cervi, Massuchin e Tavares, 2012; Dias, 2013). Portanto, se a influência do HGPE na decisão do eleitor não é nula, mesmo havendo tais constrangimentos e a construção direcionada de informações pelos principais veículos de informação da grande mídia, ele se mostra como um elemento importante no que diz respeito à própria disputa política travada entre candidatos e partidos - aqui identificada como candidaturas.

Ainda nesse sentido, após a eleição de 1994, entendemos que a relação entre candidaturas propriamente ditas (a interseção entre partido e candidato) é outro elemento que afeta sobremaneira a organização e a direção dadas aos programas veiculados no HGPE em se tratando de campanhas eleitorais a cargos majoritários. É nesse contexto, em que o HGPE é visto como importante não só na decisão do eleitor como também na constituição das identidades partidárias envolvidas, que a relação antagônica emerge no sentido de produzir discursos que busquem desconstruir a "imagem discursiva" de seus adversários (os discursos em si). Ou seja, há aqui disputas por sentidos. Essa compreensão está respaldada na teoria do discurso desenvolvida por Laclau e Mouffe (2015) e 
posteriormente ampliada por Laclau (2000, 2011, 2013, 2014), a qual entende que o conflito/disputa política é marcado por elementos antagônicos.

A respeito da relação construída entre o Partido da Social Democracia Brasileira (PSDB) e o Partido dos Trabalhadores (PT) até os dias atuais, a eleição de 1994 pode ser percebida como o primeiro momento antagônico entre os partidos e seus integrantes no cenário político/partidário brasileiro. Antes aproximados, como durante a elaboração da Constituição de 1988 (o PSDB não havia sido fundado até esse momento, mas podemos pensar, conforme o estudo de Kinzo (1989), a posição do partido a partir de seus futuros fundadores e integrantes) e a eleição de 1989, foi a partir do governo de Itamar Franco, do Partido do Movimento Democrático Brasileiro (PMDB), e evidentemente durante a eleição presidencial de 1994 que se iniciaram as disputas antagônicas entre os partidos e seus integrantes, o que se mantém até os dias de hoje em diversos níveis institucionais, como, por exemplo, dentro do Congresso Nacional.

Com isso, o objetivo deste artigo consiste em demonstrar a construção antagônica entre os discursos produzidos pelas candidaturas de PSDB e PT realizados durante o HGPE veiculados pela televisão na eleição presidencial de 1994, que acabou colocando o Plano Real como o ponto nodal desse conflito ${ }^{2}$. Temas variados foram significados durante os programas eleitorais do PSDB e do PT veiculados no HGPE durante a eleição de 1994 (Porto e Guazina, 1999), mas, exceto o tema "Plano Real", não apresentaram sentidos antagônicos entre as candidaturas estudadas. Dessa maneira, o "ponto privilegiado" na relação antagônica estabelecida entre as candidaturas foi concentrado em torno do "Plano Real". Em alguns momentos, outros temas apareceram ligados diretamente com o entendimento de cada candidatura em relação ao Plano, como evidenciado por Porto e Guazina (1999, p. 27). Por isso, o retorno ao passado neste artigo se justifica por dois principais motivos: a) esse momento pode ser lido como sendo o primeiro grande antagonismo entre os partidos PSDB e PT; e b) pouca ou nenhuma atenção foi dada pelos estudos que envolveram o HGPE à dimensão antagônica, o que pode iluminar mais um dos aspectos referentes à decisão do voto por parte do eleitor, visto a relação de desconstrução entre as candidaturas.

No momento em que este artigo foi escrito, o cenário político/eleitoral de 2018 dava demonstrações de disputas antagônicas referentes à candidatura de Jair Bolsonaro, do Partido Social Liberal (PSL), no sentido tanto de sua desconstrução como no fortalecimento de suas posições políticas. Partindo tanto da sociedade como do próprio campo político, as posições políticas apresentadas pela candidatura de Bolsonaro, que também se constitui na representação de seu vice, Antônio Hamilton Martins Mourão (o "General Mourão"), do Partido Renovador Trabalhista Brasileiro (PRTB), passaram a ser disputadas; desconstruídas por um lado e sustentadas por outro. Com o início do HGPE, a

\footnotetext{
2 Os estudos de Mendes e Venturi (1994), Amaral (1995), Jorge (1995), Almeida (1996, 1998), Miguel (1997), Porto e Guazina (1999), Mendes (2004) e Oliveira (2005) também identificaram a centralidade do Plano Real nessa eleição.
} 
dinâmica da desconstrução da candidatura de Bolsonaro se tornou mais evidente, principalmente a partir das posições políticas das candidaturas de Geraldo Alckmin do PSDB, Ciro Gomes do Partido Democrático Trabalhista (PDT), Marina Silva da Rede Sustentabilidade (REDE) e Guilherme Boulos do Partido Socialismo e Liberdade (PSOL). Ainda, outras disputas antagônicas são reveladas: primeiramente um "bloco" de candidaturas contra a candidatura representada por Bolsonaro; posteriormente uma disputa para ver quem chegaria ao segundo turno contra o próprio Bolsonaro; e, logo em seguida, uma tentativa de desconstrução tanto da candidatura de Bolsonaro como da de Fernando Haddad (PT), significadas pelas candidaturas de Geraldo Alckmin, de Ciro Gomes e de Marina Silva como extremistas e nefastas para a democracia. No segundo turno, a disputa discursiva travada entre Bolsonaro (PSL) e Haddad (PT) expôs velhos sentidos que estavam em jogo; desde "questões morais" até "projetos econômicos" apareceram em seus pronunciamentos ${ }^{3}$.

O esforço do artigo, assim, além de evidenciar o primeiro grande antagonismo entre PSDB e PT, é o de apontar a construção discursiva antagônica entre candidaturas como elemento relevante numa disputa política e eleitoral, bem como ponto de reflexão sobre os processos políticos envolvendo outros contextos eleitorais e outros antagonismos levando em consideração suas dinâmicas, continuidades e descontinuidades. Em se tratando do cenário político-eleitoral de 2018, havia evidências de relações antagônicas envolvendo as candidaturas peessedebista e petista; comparadas com a eleição de 1994, podem-se apontar como continuidades à disputa em torno da compreensão dos modelos econômicos adotados pelos governos de Fernando Henrique Cardoso (doravante FHC) do PSDB (1994-2002) e Lula (2003-2010) e Dilma Rousseff (2011-2016) ${ }^{4}$, do PT. O ainda recente contexto eleitoral de 2014 e seus desdobramentos políticos e/ou eleitorais, em que Dilma Rousseff (PT) chegou à frente de Aécio Neves (PSDB), o questionamento da validade do resultado da eleição de 2014 por parte da candidatura peessedebista e a articulação política envolvendo integrantes do PSDB requerendo o impeachment de Dilma Rousseff foram refletidos na eleição de 2018. Por isso, o retorno ao passado na busca de um renovado olhar sobre as relações antagônicas, nesse caso em relação aos partidos PSDB e PT, ajuda a compreender as continuidades de cenários políticos bem como suas descontinuidades.

Com esse objetivo em foco, são utilizados os aspectos teóricos e metodológicos da teoria do discurso de Laclau e Mouffe (Laclau e Mouffe, 2015; Laclau, 2000, 2011, 2013, 2014), enfatizando os conceitos de discurso e antagonismo, imprescindíveis para a captura dos sentidos discursivos que aqui são demonstrados.

Para isso, este artigo está dividido em quatro seções, mais as conclusões. Na primeira seção, "A teoria do discurso de Laclau e Mouffe, são apresentados os aspectos

\footnotetext{
3 Este artigo foi finalizado antes do final do segundo turno da eleição de 2018.

4 Dilma, acusada de "pedaladas fiscais" e "liberação de créditos suplementares" sem prévia autorização do Legislativo, teve o mandato cassado no final de agosto de 2016.
} 
teóricos e metodológicos da teoria do discurso de Laclau e Mouffe. Na segunda seção, "As trajetórias de PT e PSDB até as eleições de 1994 e o contexto da emergência dos discursos antagônicos", são apresentadas as trajetórias de formação de PT e PSDB, indicando o processo de aproximação e distanciamento entre os partidos até o contexto político da eleição de 1994, bem como uma rápida contextualização do Plano Real e das regras do HGPE para essa eleição. Na terceira seção, "O Plano Real no discurso do PSDB", é apresentado o discurso produzido pela candidatura do PSDB durante os programas eleitorais veiculados no HGPE na eleição de 1994, a qual colocou o Plano Real como seu ponto nodal. Na quarta seção, "O Plano Real no discurso do PT", é apresentado o discurso produzido pela candidatura do PT durante os programas eleitorais veiculados no HGPE na eleição de 1994, tendo o Plano Real como seu ponto nodal; ou seja, o Plano se constituiu como o ponto antagônico entre as candidaturas. Por fim, nas "Conclusões" é retomado o debate proposto neste artigo e são apresentados os resultados objetivos.

\section{A teoria do discurso de Laclau e Mouffe: aspectos teóricos e metodológicos}

A teoria do discurso desenvolvida por Laclau e Mouffe carrega uma série de conceitos que permitem leituras de realidades complexas, bem como, do ponto de vista metodológico, a organização dessa realidade de forma a torná-la "legível". Com isso, o objetivo desta seção é apresentar os conceitos da teoria do discurso, os quais serão utilizados tanto para as análises quanto para a organização metodológica dos dados extraídos dos pronunciamentos contidos nos programas eleitorais do PSDB e do PT veiculados no HGPE no período da campanha eleitoral de 1994.

Para Laclau e Mouffe (2015, p. 180), todo objeto é uma formação discursiva em que nenhuma significação pode ser constituída fora disso, ou seja, todo objeto é constituído a partir do social, que, por sua vez, é discursivo. Sendo assim, o social é necessariamente um social simbólico, discursivo e fundado a partir da relação política. Conforme os próprios autores:

a) O fato de que todo objeto é constituído como objeto de discurso não tem nada a ver com a existência de um mundo externo ao pensamento, nem com a oposição realismo/idealismo. Um terremoto ou queda de um tijolo é um evento que certamente existe, no sentido de que ocorre aqui e agora, independente de minha vontade. Mas, se sua especificidade como objeto será construída seja em termos de um fenômeno natural ou como expressão da ira de Deus, vai depender da estruturação de um campo discursivo. O que se nega não é que tais objetos existam externamente ao pensamento, mas antes a afirmação bastante diferente de que eles próprios possam se constituir como objetos fora de qualquer condição discursiva de emergência. 
b) Na origem do preconceito anterior reside a suposição do caráter mental do discurso. Contra isso, afirmamos o caráter material de toda estrutura discursiva (...). Os elementos linguísticos e não linguísticos não são meramente justapostos, mas constituem um sistema diferencial e estruturado de posições - isto é, um discurso. As posições diferenciais incluem, portanto, uma dispersão dos diversos elementos materiais (Laclau e Mouffe, 2015, p. 181-182).

Para essa corrente de pensamento, um discurso é uma prática articulatória e significativa que constitui e organiza relações sociais, como apresentada no exemplo do excerto acima. Além do mais, o linguístico não pode ser visto separado do social, rechaçando toda e qualquer separação entre práticas discursivas e práticas não discursivas, pois o discurso não possui um caráter meramente mental, mas sim material. Com isso, existe uma relação entre a fala (o linguístico) e o que ela significa (a materialidade do discurso - seu significado), formando uma totalidade significativa. Nesse sentido, o discurso é mais do que a união entre gesto e fala, ele é uma relação de significação (Mendonça, 2007, p. 250).

Toda configuração social é uma configuração significativa, pois são atribuídos aos eventos sociais diferentes significados, ou seja, um acontecimento pode gerar vários significados diferentes, dependendo do contexto em que está inserido. Segundo Pinto (2006, p. 80), para a teoria do discurso, a verdade é uma construção discursiva, é a tentativa de dar sentido ao "real", uma tentativa de fixar sentidos no âmbito do social. Discurso, por isso, é entendido a partir de um conjunto de elementos em que as relações desempenham um papel constitutivo na sua simbolização; "Isso significa que os elementos não preexistem ao complexo relacional, mas se constituem através dele" (Laclau, 2013, p. 116). Em virtude disso, não existe nada que ultrapasse o jogo das diferenças assumindo um caráter de fundamento anterior ao próprio jogo.

O campo discursivo é o espaço onde diversas formações discursivas entram em concorrência umas com as outras e formam um jogo de equilíbrio instável entre diversas forças. Um discurso se forma sempre na tentativa de dominar o campo da discursividade, buscando, desse jeito, se constituir como um ponto nodal, um ponto privilegiado, um discurso hegemônico (Laclau e Mouffe, 2015, p. 187). Vejamos tal definição segundo os próprios autores:

(...) chamaremos articulação qualquer prática que estabeleça uma relação entre elementos de tal modo que a sua identidade seja modificada como um resultado da prática articulatória. A totalidade estruturada resultante desta prática articulatória, chamaremos discurso. As posições diferenciais, na medida em que apareçam articuladas no interior de um discurso, chamaremos momentos. Por contraste, chamaremos elemento toda diferença não discursivamente articulada (Laclau e Mouffe, 2015, p. 178). 
Uma vez compreendida a relação entre discurso e prática articulatória, é importante esclarecer a relação entre lógica da equivalência e lógica da diferença. No momento da articulação, tanto a lógica da equivalência como a lógica da diferença operam. No caso da lógica da diferença, sua principal característica perpassa o entendimento de que esse momento diferencial não impede sua articulação com outro elemento. É o fato de existir o "diferencial" que torna tal articulação possível; o diferencial nada mais é que a particularidade de um elemento mantida em sua transição para o status de momento de uma cadeia articulatória. Já a noção de lógica da equivalência demonstra a similaridade de determinado aspecto no momento articulatório. Dentro do campo discursivo, é a lógica da equivalência que forma a articulação de elementos que passaram a ser considerados momentos dessa cadeia. É importante deixar claro que a equivalência representada no status de momento não elimina a diferença do status de elemento.

A articulação discursiva, para existir, precisa de um exterior constitutivo, que é a marca do antagonismo, é o discurso antagônico ${ }^{5}$. Isso significa que a relação antagônica dá início à construção de identidades políticas a partir de uma relação com o "Outro"; o antagonismo, marcado pela falta, pelo deslocamento de toda identidade, é a possibilidade da articulação que formará o discurso e, por consequência, se condensará a partir de um ponto nodal. O ponto nodal dessa formação discursiva assume uma característica fundamental na construção do próprio discurso, pois é através dele que se estabelece a união entre os momentos diferenciais. É um ponto discursivo privilegiado que aglutina outros discursos em torno de si, determinando os limites desse discurso, do que está articulado e do que não está, ou seja, o que ele representa e o que não representa.

Com isso, as práticas articulatórias são constituídas em torno de pontos nodais e, ao mesmo tempo, são suas constituidoras. Dessa forma, um ponto nodal é onde as significações serão articuladas, ou seja, onde a lógica da equivalência irá subverter, em partes, todas as diferenças das identidades articuladas com esse ponto privilegiado. Mendonça (2003a, p. 143) afirma que os pontos nodais são fundamentais para a prática articulatória, pois, por serem pontos discursivos privilegiados, eles possuem a capacidade de fixar, mesmo que de forma precária, a própria articulação. O ponto nodal é delimitado pelo seu corte antagônico, seu exterior constitutivo, ou seja, em uma disputa discursiva um ponto nodal sempre terá o seu antagônico. Em vista disso, todo ponto nodal se constitui em uma luta por hegemonia e, nesse sentido, quando uma determinada identidade se hegemoniza, esvaziando sua particularidade inicial, se torna, necessariamente, um significante vazio.

Neste momento, a partir da lógica laclauniana, é pertinente a compreensão do conceito de "hegemonia" desenvolvido no âmbito da teoria do discurso aqui tratada. É importante percebermos que o momento da hegemonia é fruto dessa formação discursiva e, assim, a hegemonia de um discurso, no sentido desenvolvido por Laclau e Mouffe, é a

5 Uma revisão e interpretação sobre o conceito de antagonismo pode ser encontrada em Mendonça (2003a, 2010, 2012). 
representação de um particular que se esvazia para se tornar um universal representativo. Todo discurso busca se hegemonizar, ou seja, uma identidade tenta impor sua particularidade sobre outra, mesmo que seu sentido nunca seja plenamente constituído; e é disso que decorre a impossibilidade de totalização, de formação de um discurso pleno. Todo instante hegemônico necessita de uma relação antagônica, pois o momento em que uma identidade particular atinge a hegemonia é precedido por algum discurso que o antagonizava ou ainda se mantém como antagônico. Por outro lado, mesmo que haja uma hegemonia, o social ainda se mantém fragmentado por diversas lutas antagônicas, o que poderá ameaçar a hegemonia "dominante".

Mendonça (2007, p. 251) afirma que todo processo hegemônico parte de uma identidade particular que consegue representar discursos ou identidades antes dispersas no campo da discursividade. A hegemonia, nesse sentido, é um lugar vazio; para atingir a posição hegemônica uma determinada identidade terá de esvaziar suas particularidades na busca de representar outras tantas identidades, à vista disso, universalizar seus sentidos. No espaço do social pode haver vários pontos de hegemonia decorrentes dos antagonismos. Todos os discursos buscam universalizar seus conteúdos particulares, ou seja, toda formação discursiva tem como objetivo expandir seu sentido na busca de se tornar um discurso sistematizador, um discurso hegemônico. Nas palavras dos autores: "(...) a hegemonia emirja num campo atravessado por antagonismo e, portanto, supunha os fenômenos da equivalência e os de fronteira. Porém, inversamente, nem todo antagonismo supõe práticas hegemônicas" (Laclau e Mouffe, 2015, p. 215).

Um discurso hegemônico é sempre um discurso sistematizador, pois ele aglutina outros sentidos, ou seja, hegemonia é quando uma identidade, de forma precária e contingente, passa a representar diversas outras identidades dentro desse discurso. Com isso, o discurso sistematizador acaba abarcando novos sentidos, o que faz com que seu conteúdo original seja modificado, pois para buscar essa hegemonia ele tem de ampliar seus conteúdos. Consequentemente, é através dessas disputas hegemônicas que se constituem os discursos políticos, ou seja, a hegemonia parte de qualquer relação de luta política (Laclau e Mouffe, 2015, p. 219).

Para além da divisão do espaço do social em dois polos antagônicos - no sentido de populismo desenvolvido por Laclau (2013) -, é preciso compreender a hegemonia a partir da fragmentação e da formação de disputas discursivas específicas. Nesse sentido, quando tratamos de uma disputa imersa no espaço do social, mas que não coloca em xeque sua estruturação mais estável (sua hegemonia ainda incontestável), mas sim uma disputa mais "particularista", como, por exemplo, a luta entre os ecologistas e a monocultura de eucalipto no interior do Rio Grande do Sul (Vieira Junior, 2010), é possível identificar dois discursos hegemônicos a partir da posição de seus momentos. O que se quer dizer com isso é que, ao levar em consideração a formação interna de cada discurso a partir de suas articulações, é possível perceber que essa formação institui um momento hegemônico interno ao discurso. Num outro momento, a partir da compreensão relacional 
com o discurso antagonizado, o que está em disputa é exatamente o caráter hegemônico sobre os aspectos daquela luta política - se o mais importante é a ecologia ou a relação com o mercado da monocultura. Ainda nesse contexto, podemos identificar um discurso hegemônico e, por isso, sistematizador do social, sendo combatido por diversos outros discursos antagônicos, sem que estes assumam uma posição hegemônica nesse recorte específico.

É nesse sentido que, segundo Laclau e Mouffe (2015, p. 218-219), nenhuma lógica hegemônica pode dar conta de uma totalidade do social, ou seja, nenhuma determinada identidade pode representar o todo social, pois, como já havíamos destacado anteriormente, todo processo hegemônico necessita de uma relação de antagonismo, até mesmo se pensarmos em disputas arrefecidas. Com isso, todo processo hegemônico tem o seu lado negativo - ou vários, entendidos como pontos de tensão. Além do mais, toda hegemonia se constitui a partir de um antagonismo, tornando-se um significante vazio.

Outro conceito de grande importância para a teoria do discurso é a noção de significante vazio. Segundo Laclau, "um significante vazio é, no sentido estrito do termo, um significante sem significado" (Laclau, 2011, p. 67). Um determinado discurso, um ponto nodal, abarca tantos significados de vários momentos que se articularam em torno dele, que acaba esvaziado de suas particularidades e representando outras particularidades dessas identidades articuladas com ele. Para Mendonça (2003b, p. 67), um significante vazio é um significante sem significado em função de uma polissemia de sentidos que estão articulados em torno de seu significado. Segundo o autor, isso faz com que este esvazie seus conteúdos específicos na busca de representar tantas outras identidades, tornandose, desse modo, um significante sem um significado específico. Com isso, ele representa muitas outras identidades, mas nenhuma única em particular, e assim se torna significante vazio. Tal vazio é entendido a partir de uma abundância de sentidos, e não pela ausência deles.

Para Laclau (2011, p. 75), o significante pode estar vinculado a distintos significados. Isso quer dizer que demandas diferentes, com sentidos diferentes, se articulam em torno de um ponto nodal, um ponto que teve a sua particularidade universalizada, tornou-se um significante vazio. Segundo Laclau, o significante vazio, uma diferença particular que assumiu o papel de representação - sem deixar de ter sua particularidade - representa todas as identidades particulares que estão articuladas com esse significante.

A existência de forças antagônicas e a instabilidade das fronteiras entre elas, que constitui a relação entre equivalência e limite, são marcadas pela relação de flutuação entre elementos que aparecem nesses discursos ainda em formação, o que possibilita a construção de uma hegemonia. A formação de pontos nodais e a construção de uma relação hegemônica só são possíveis tendo em vista o fato de que todo significado é vazio, dependendo da relação de formação desse significado. Por consequência, por meio desses processos são construídos os discursos. 
O antagonismo só pode emergir numa relação complexa de significação em que o discurso é formado e constitui as relações materiais. Isso posto, Laclau e Mouffe (2015, p. 199-200) descartam a relação antagônica como uma oposição real ou como uma contradição, conforme foi desenvolvida por Colletti (1975) a partir de sua interpretação de Kant. O choque entre dois objetos não elimina sua existência física e a oposição real ocorrida entre eles. Além disso, muitas relações contraditórias emergem do social sem, necessariamente, constituir uma relação antagônica. O antagonismo é um conceito específico que não mantém relação direta e necessária com a ideia de oposição real e de contradição lógica (Laclau, 2014, p. 129). No terreno da teoria do discurso dos autores aqui tratados, o antagonismo constitui determinadas identidades a partir de articulações discursivas marcadas pela negação de sua expansão dentro de um jogo simbólico de significados e sentidos. Enquanto oposição real e contradição se originam do entendimento de que suas identidades já são plenas e constituidoras de uma totalidade (mesmo no caso físico, para oposição). A presença do discurso antagonizado impossibilita essa totalização (Laclau e Mouffe, 2015, p. 201-202), tendo em vista a presença do "outro".

Então, para Laclau e Mouffe (2015, p. 202), todo discurso que nega o outro se constitui como antagônico, pois, ao mesmo tempo em que ele delimita seu corte antagônico, seu opositor, ele se constitui como "ele mesmo", portanto, a negação do outro é ao mesmo tempo a possibilidade de constituir sua própria identidade, como também a impossibilidade do antagonizado constituir plenamente a sua identidade. Ainda segundo os autores, na formação do social há possibilidade da existência de vários antagonismos:

Até agora, ao falarmos de antagonismos, temos conservado o termo no singular a fim de simplificar nosso argumento. Mas é claro que o antagonismo não necessariamente emerge em um único ponto: qualquer posição num sistema de diferenças, na medida em que é negada, pode tornar-se o locus de um antagonismo. Desta forma, há uma variedade de antagonismos possíveis no social, muitos deles em oposição uns aos outros (Laclau e Mouffe, 2015, p. 209).

As lutas democráticas emergem num contexto marcado por uma dupla característica que pode parecer paradoxal: o campo é relativamente suturado e, ao mesmo tempo, as identidades sempre deslocadas (Laclau, 2000, p. 37) expressam seu caráter fragmentado. Isso implica a compreensão de que o espaço social é "formado por uma multiplicidade de práticas que não esgotam a realidade referencial e empírica dos agentes que fazem parte dela" (Laclau e Mouffe, 2015, p. 210-211). No entanto, para que o antagonismo ocorra, é necessário compreender que toda identidade é deslocada e marcada por uma falta constitutiva e, ao mesmo tempo, sempre em busca de uma certa sedimentação. Com isso, o fato de o social ser "relativamente suturado" não significa que ele está fundado numa objetividade última, mas sim que seu caráter é precário. Logo, sua precariedade e contingência indicam sua fragmentação como social e as múltiplas 
possibilidades de articulações discursivas, o que, por outro lado, não elimina uma possível articulação com outros discursos na formação de um discurso mais amplo que possa dividir o social em dois polos. Segundo a teoria do discurso, esse é o caminho do populismo (Laclau, 2013).

A lógica antagônica possibilita compreender as relações políticas a partir de identificações, demostrando que tais lutas não resultam de identidades prontas, mas sim as formam. Nesse sentido, a realidade social não pode ser simplesmente descrita por relações preestabelecidas, mas sua complexidade aparece no instante em que tais relações se mostram sempre precárias e contingentes - o momento de suas formações.

No que se refere aos aspectos metodológicos da teoria do discurso aqui utilizada, bem como à estratégia organizacional propiciada por ela, é necessário capturar a formação da realidade construída - nesse caso o HGPE e a disputa política eleitoral entre as candidaturas do PSDB e do PT - e nela identificar os elementos dispersos que apresentem regularidades na produção de sentidos em cada formação discursiva a partir da relação antagônica estabelecida, ou seja, as disputas por determinados sentidos. Identificadas as regularidades nos elementos, estes passaram a ser chamados de momentos discursivos, os quais, como já mencionado, são carregados de sentidos. Realizado esse processo, o próximo passo é identificar, a partir da formação dos momentos, o ponto privilegiado dessa formação, ou seja, o ponto que condensa e constitui o discurso, o ponto nodal (aqui em torno do Plano Real). Isso identificado, a etapa seguinte é apontar, a partir da relação antagônica estabelecida entre os discursos, a estruturação dessa formação discursiva; a relação antagônica, o ponto de antagonismo, é representada, nesse momento, pelo ponto nodal - como já afirmamos no decorrer deste artigo, toda relação política se constitui de forma antagônica, ou seja, toda relação de articulação interna de um determinado discurso só é possibilitada por um exterior ameaçador. Esse momento é o momento da formação/reconfiguração de identidades a partir de identificações políticas precárias e contingentes: a relação, propriamente dita, estabelecida com base no antagonismo entre os discursos formados a partir dos pronunciamentos contidos nas candidaturas do PSDB e PT durante o HGPE na eleição em questão, de 1994.

\section{As trajetórias de PT e PSDB até as eleições de 1994 e o contexto da emergência dos discursos antagônicos}

O principal objetivo desta seção é o de situar o leitor sobre os aspectos basilares dos partidos PT e PSDB, bem como apontar a relevância do Plano Real e explicar o contexto do HGPE para a eleição de 1994. Para isso a seção está dividida em três subseções. A intenção das duas primeiras é tão somente a de apresentar dois dos diversos aspectos das trajetórias políticas de PT e PSDB: suas formações enquanto partido e, paralelamente, a relação que emergiu entre os partidos até a eleição de 1994. Há outros estudos, que serão citados ao longo desta seção, que apresentam outros aspectos desses partidos. Já a 
terceira seção, como enunciado, tem como função contextualizar o Plano Real e o HGPE na eleição de 1994.

O caso do PT

Com a expansão da classe operária a partir dos anos 1960, as transformações sociais, econômicas e políticas criaram um ambiente em que o debate em torno dos direitos dos trabalhadores das fábricas insuflou os ânimos a partir da necessidade de uma organização política maior. A formação dos sindicatos nas "grandes" cidades industriais propiciou o surgimento de novas lideranças políticas no Brasil, principalmente a partir de 1977, quando o novo sindicalismo passou a denunciar a política de arrocho salarial implementada pelo governo da época. Nesse contexto, em que o novo sindicalismo questionava as organizações econômicas e políticas originadas durante o regime militar (Amaral, 2003, p. 27-28) ${ }^{6}$, novas lideranças começam a conduzir os trabalhadores na luta por seus direitos e por salários mais dignos. Esse foi o elemento fundamental na formação, organização e estruturação das bases do que se tornaria o Partido dos Trabalhadores (PT). Foi durante essa mobilização que a figura de Lula surgiu como um de seus principais líderes políticos e um dos mais importantes porta-vozes das demandas dos sindicalistas e, com o fim do bipartidarismo, um dos principais articuladores para a criação do novo partido, o PT.

Com uma estrutura variada, mas com forte base nos sindicatos, a formação do partido contou em sua composição social com intelectuais, pessoas ligadas à Igreja Católica, com grande parte da classe trabalhadora e sindicatos vinculados às fábricas do ABC paulista - os metalúrgicos -, como também com os bancários ligados ao Banco do Brasil (Rodrigues, 2002; Amaral, 2003; Reis, 2010). Além disso, a militância foi um elemento que caracterizou o movimento formador do partido e suas atividades políticas na sociedade, o que o diferenciou, assim, dos outros partidos brasileiros (Terron e Soares, 2010, p. 312). Segundo Meneguello (1989, p. 91), o PT, no momento de sua formação, conferia muito mais importância às relações construídas com os movimentos sociais do que à atividade eleitoral e parlamentar? .

A partir do Estatuto de criação do PT (Manifesto de Fundação do PT, 1980) e entre 1989 (primeira eleição direta para presidente após a redemocratização) e 1998, os programas de governo do PT (Programas PT, 1994, 1998) não apresentaram mudanças substanciais. A partir desse período, os programas foram ganhando novos elementos que configuravam o contexto político daqueles momentos. Como era de se esperar de um

\footnotetext{
${ }^{6}$ Após o golpe político em 1964, os militares, principal grupo envolvido no golpe e responsável pelo governo durante o período repressivo, valendo-se de sua posição, aproveitaram para reprimir os movimentos sindicais da época.

7 Para outras informações sobre o partido, ver Samuels $(2004,2008)$.
} 
partido originário da esquerda, o principal ponto defendido - que permeava todas as outras questões - era a diminuição da desigualdade e a inclusão social do cidadão.

Ligado à esquerda socialista ${ }^{8}$, o partido defendia políticas tidas como radicais, como a suspensão do pagamento da dívida externa (Programa PT, 1989, 1994). Segundo esses Programas, a dívida externa já teria sido paga e a cobrança dos juros era abusiva, por isso a defesa de suspender seu pagamento até que isso fosse revisto. Com a suspensão desse pagamento sobraria mais dinheiro para investir em projetos sociais, como a construção de habitação para classes mais desfavorecidas e a elaboração de programas que buscassem a erradicação da fome e o fim do analfabetismo ${ }^{9}$. Conforme os Programas de Governo do PT $(1989,1994)$, o projeto econômico implementado no país não conciliava a ideia de desenvolvimento econômico com desenvolvimento social, primordial para equilibrar a economia e diminuir as desigualdades. Os governos até então se preocupavam apenas com a estabilidade econômica sem levar em consideração as desigualdades existentes, diminuindo o crédito para as classes mais baixas e não desenvolvendo políticas públicas de habitação.

Nesse mesmo período, as alianças políticas construídas pelo partido sempre se mantiveram à esquerda do espectro político nacional. Conforme Garcia (2012, p. 94), enfatizando o Programa de Governo do PT de 1989, definiu-se que o partido não faria coligações e alianças políticas com "partidos burgueses". As campanhas eleitorais eram vistas como mais do que uma simples campanha para ocupar cargos públicos eletivos, eram mobilizações de luta e de denúncia, que buscavam apresentar a situação em que o povo se encontrava perante o sistema instituído, ou seja, não bastava simplesmente eleger candidatos, era preciso informar o cidadão.

Em 1989, quando o partido e Lula aceitaram o apoio de FHC no segundo turno da eleição, os dois partidos e seus integrantes se uniram contra as estruturas da ditadura que ainda se mantinham fortes nas instituições políticas. Nessa mesma eleição, os partidos de esquerda que apresentaram candidatos à presidência da República anunciaram apoio a Lula no segundo turno - o candidato à vice-presidência na chapa de Lula era José Paulo Bisol, do Partido Socialista Brasileiro (PSB). O PT e Lula só não aceitaram o apoio de Ulysses Guimarães e do PMDB porque o governo anterior, de José Sarney, tinha tido uma péssima avaliação pela opinião pública e pela mídia (Amaral, 2003, p. 68-70).

Na eleição de 1994, o PT decidiu construir uma candidatura "puro sangue", com Lula para presidente e Aloizio Mercadante como vice; o PSB compôs a coligação. Já para a eleição de 1998, a frente de esquerda comandada pelo PT e por Lula, além de manter o

\footnotetext{
8 Segundo Garcia (2012, p. 93), o PT nunca se reivindicou como um partido marxista, contudo sempre assumiu posições políticas ligadas ao socialismo e contra a ideia capitalista. Após 1989, o partido passou a debater suas ideias contra o modelo dominante, o neoliberalismo. Para outras informações que abarcam o entendimento da esquerda no Brasil, ver Soares (2006).

9 Outras informações podem ser encontradas em Manifesto de Fundação do Partido dos Trabalhadores (1980). Disponível em: <http://www.pt.org.br/manifesto-de-fundacao-do-partido-dos-trabalhadores/>. Acesso em: 6 dez. 2018.
} 
apoio do PSB, ganhou um apoio importante: Leonel Brizola, candidato à presidência pelo Partido Democrático Trabalhista (PDT) em 1989 e 1994, foi indicado como vice na coligação. Mesmo abrindo mão de elementos mais radicais em 1998, a principal aliança a contradizer as bases históricas do partido ocorre em 2002, com a indicação de José Alencar, do Partido Liberal (PL), para vice-presidente da coligação. Além disso, a eleição de 2002 marcou diferenças substanciais no partido ${ }^{10}$.

É a partir dessa eleição que algumas alterações de posições adotadas pelo partido e por parte de seus integrantes, principalmente os apoiadores de Lula, são percebidas. Como já mencionado, as alianças políticas se tornam mais heterogêneas, a começar pela indicação de José Alencar ( $\mathrm{PL}$ ) para vice. Além disso, por mais que existam elementos estruturais impostos pelo sistema político (o governo de coalizão), o PT aceitou o apoio do PMDB no Congresso Federal, partido aliado do PSDB em seus governos e que compunha a chapa com a indicação de Rita Camata a vice-presidente em $2002^{11}$.

O contexto político iniciado na eleição de 1989 é um marco na trajetória políticopartidária do PT. Vislumbrando a possibilidade real de vitória nessa eleição, o partido dá início a pequenas mudanças estruturais. A eleição de 1994, neste sentido, e levando em consideração a dimensão de identificação política, é o momento inicial de disputas com o PSDB, o que também afeta esse processo de "metamorfose".

\section{O caso do PSDB}

Com o fim do bipartidarismo e a formação de novos partidos ocupando posições distintas no espectro político/ideológico na "Nova República" (Mainwaring, 2001; Motta, 2008), as disputas em torno do novo modelo democrático se estenderam e propiciaram debates mais fortes dentro dos próprios partidos recém-formados e/ou em processo de formação. Assim, durante a Assembleia Constituinte (1985-1988) ocorreram muitas disputas ideológicas, inclusive dentro do PMDB, partido herdeiro do Movimento

\footnotetext{
10 Estudos, como os de Amaral (2003) e Garcia (2012), apresentam diversos aspectos das mudanças ocorridas no partido. Em se tratando de mudanças em campanhas para presidente da República, ver Mendes (2004). Para mais informações, ver Oliveira (2005).

11 Amaral (2003, p. 158), analisando os programas do partido de 1989 a 2002, afirma que em 1998 o partido abandonou questões mais ideológicas ligadas ao socialismo e passou a se preocupar em construir projetos com propostas mais específicas. Além disso, é importante perceber que o partido passou a dialogar com outros grupos da sociedade, buscando, com isso, ampliar a sua base eleitoral. Antes preocupado com as questões dos trabalhadores, a partir de 1998 e principalmente após 2002, o partido demonstrou uma preocupação de aspecto eleitoral. Identificou a necessidade de ampliar suas bases para conseguir eleger o presidente da República - é salutar destacar que tal mudança pragmática nunca foi unanimidade no partido. Desde 2002, o PT tornou-se mais moderado e muito menos preocupado com os princípios ideológicos e partidários de seus anos iniciais. O PT sucumbiu à lógica das grandes campanhas eleitorais comandadas por "marqueteiros". As doações de campanha vieram de grandes empresas e de empresários conhecidos, ou seja, o PT aceitou as imposições da burguesia para consolidar sua campanha e ter possibilidade real de vitória (Garcia, 2012, p. 102, p. 106). Outros estudos sobre o PT abordam perspectivas diferentes. Ver Singer (2009, 2010, 2012) e Rennó e Cabello (2010) para uma melhor compreensão sobre a relação do partido com suas bases eleitorais.
} 
Democrático Brasileiro (MDB), e que originaram os principais partidos de esquerda nesse novo momento (Rodrigues, 1987).

A partir de disputas ideológicas em torno da definição da Constituinte, alguns integrantes do PMDB, que não concordavam com a posição adotada pelo partido na Constituinte, decidiram abandonar o partido e fundar um novo. Alguns integrantes não aceitavam o fato de o partido ter realizado alianças com a direita. A aliança com o Partido da Frente Liberal (PFL), partido dissidente da Aliança Renovadora Nacional (Arena) ${ }^{12}$, e, além disso, a disputa entre presidencialismo e parlamentarismo alimentaram a emergência de um racha interno no PMDB. Os descontentes queriam que a Assembleia Constituinte definisse o Parlamentarismo como forma de governo. Essa divergência interna no PMDB, evidenciada durante a Assembleia Nacional Constituinte (ANC), teve um novo episódio. Membros do PMDB - os desgarrados - votaram a favor dos quatro anos de mandato para o Presidente da República, apesar de a maioria da bancada do partido e de políticos conservadores agrupados no "Centrão", grupo suprapartidário formado em fins de 1987, ter decidido pelos cinco anos de mandato. Outro elemento relevante que levou a essa separação foi a centralidade decisória e a hierarquia estruturada do PMDB (Roma, 2002, p. 73-74).

Graças à vitória de Tancredo Neves no colégio eleitoral, em 1984, a Aliança Democrática - com apoio de dissidentes do Partido Democrático Social (PDS) - começou a aceitar a adesão de políticos que antes eram considerados inimigos. Além disso, o PMDB começou a realizar uma distribuição de cargos que não agradou parte de seus integrantes, o que causou insatisfação com relação à deturpação de sua história; um partido oposicionista que acabava perdendo suas características ao se tornar governo.

No dia 25 de junho de 1988, esse grupo ainda pertencente ao PMDB, capitaneado, basicamente, por pessoas de São Paulo e Minas Gerais, externalizou sua insatisfação com o governo Sarney e propôs a criação desse novo partido, o Partido da Social Democracia Brasileira (PSDB) $)^{13}$. Entre os fundadores do novo partido estavam nomes de "peso" do estado de São Paulo, como Franco Montoro, Carlos Antônio Costa Brandão, Humberto Costa Brandão, José Serra, Mário Covas, Fernando Henrique Cardoso e Geraldo Alckmin. Fora de São Paulo, o novo partido contou com o apoio de nomes importantes como Pimenta da Veiga, Eduardo Azeredo, José Richa, Teotônio Vilela Filho, Aécio Neves, Arthur Virgílio e Maria de Lourdes Abadia. Posteriormente, outros políticos com expressão local e nacional, como Tasso Jereissati e Ciro Gomes, migrariam para o partido. Levando em consideração o posicionamento dos integrantes desse novo partido, o PSDB, em relação ao seu partido

\footnotetext{
12 Como apresenta Roma (2002), o PSDB e seus integrantes, em 1994, se renderiam à necessidade de formar o governo, e se aliariam com o PFL, garantindo a vaga de vice-presidente para um partido tido de direita. Desde sua base organizacional até seu posicionamento político institucional, o PFL pode ser considerado um partido de direita; se levarmos em consideração as práticas políticas locais dos integrantes desse partido, seja no momento eleitoral ou até mesmo durante o mandato de seus políticos, tal afirmação fica mais evidente (Mainwaring, Meneguello e Power, 2000).

13 Para uma leitura complementar, ver Marques e Fleischer (1999).
} 
anterior, o PMDB, Kinzo (1989, p. 241-242) destaca que, analisando seu programa - ainda muito incipiente - e a composição social de sua bancada, o PSDB ocuparia a centroesquerda do espectro político brasileiro ${ }^{14}$.

Conforme Roma (2002, p. 72), o PSDB, por mais que se intitulasse como um partido social-democrata, se constituiu de forma diferente dos partidos da socialdemocracia clássica europeia. Esses partidos europeus se originaram articulados às massas trabalhadoras e aos sindicatos. Já o PSDB teve sua origem exclusivamente parlamentar e, desse modo, sua composição inicial era de políticos influentes no cenário político nacional.

A formação do PSDB, na ótica da produção bibliográfica brasileira sobre a formação dos partidos políticos nacionais, como afirma Roma (2002, p. 71), sempre esteve vinculada a essas questões ideológicas - sobre o posicionamento de um partido de esquerda - que levou à cisão do PMDB. Contudo, ainda segundo Roma (2002, p. 86-87), a formação do PSDB a partir da desvinculação de políticos do PMDB não teria nada de ideológico. Pelo contrário, a ruptura apresentou características pragmáticas e eleitorais. Nesse sentido, a formação do PSDB foi decorrente da busca de espaços de poder por determinados parlamentares insatisfeitos com o comando exercido pelos "caciques" do PMDB.

Roma (2002, p. 83-84) destaca ainda que, passados seis anos desde a formação do PSDB, quando o partido vence as eleições de 1994, acabou fazendo coligações justamente com o PFL, partido que era criticado pelos seus formadores e que levou, em grande medida, à separação do PMDB. Além disso, seus integrantes, principalmente FHC, buscaram apoio político na sua antiga sigla, o PMDB. Tal articulação política teve tanto êxito que se repetiu nas eleições de 1998 e garantiu, além de outros feitos, o Plano Real e a reeleição ${ }^{15}$ de FHC. Sendo assim, passados seis anos desde a sua criação, o PSDB já fazia alianças de centro-direita, o que define, além das políticas implementadas pelos integrantes desse partido, sua posição ideológica e não pragmática nesse momento político (Roma, 2002).

Após sua formação, o PSDB - uma agremiação que propiciou uma estrutura organizacional fraca e descentralizada, com baixa participação e adesão de filiados (Roma, 2002 , p. 74) -, por mais que seja apontado como uma ruptura ideológica com o PMDB, apresentou, na verdade, também segundo Roma (2002, p. 87), um alinhamento ideológico com o liberalismo/neoliberalismo mais do que com a própria social-democracia ou com políticas tidas de esquerda. Assim, o autor afirma que o PSDB, ao fazer aliança com o PFL (causada, em grande medida, pela falta de capacidade, pois o partido concentrava as suas forças basicamente em São Paulo), não estaria buscando construir uma relação pragmática/eleitoral, como afirma a bibliografia brasileira sobre esse assunto, mas sim construindo um alinhamento ideológico em busca de uma candidatura bem definida; dois

\footnotetext{
14 Existem outras classificações diferentes em relação à posição ocupada pelos partidos nesse momento. Ver Novaes (1994) e Lima Jr. (1997).

15 O debate em torno da reeleição de Fernando Henrique Cardoso foi marcado por um embate entre seu partido, o PSDB, e o PT. Esse momento político também marcou muitas acusações de corrupção, como compra de votos.
} 
partidos com políticos comprometidos com a busca eleitoral e articulados não meramente por isso, mas sim por afinidades ideológicas ligadas, em muitos aspectos, às diretrizes neoliberais ${ }^{16}$.

Segundo Guiot (2006, p. 130), o ideário neoliberal do PSDB só pôde ser percebido, de forma mais clara, quando FHC assumiu a presidência da República em 1994. Entretanto, na visão do autor, a perspectiva neoliberal sempre foi a corrente dominante no partido e a que deu sustentação a suas políticas e seus programas. Por mais que Guiot dê ênfase a essa perspectiva de posicionamento, a construção do próprio partido buscou lutar contra estruturas que foram construídas durante a ditadura, incluindo características econômicas. Quando o Programa do PSDB trata de mudanças, estas são pensadas em todas as áreas econômica, social, política, partidária etc. Esses elementos são definidos como reformas (Programa PSDB, 1988) ${ }^{17}$. Porém, e Guiot deixa claro isso, a visão liberal era dominante e as reformas pretendidas não viriam de um Estado forte, mas sim a partir dos conflitos da sociedade, ou seja, com pouca ou quase nenhuma intervenção do Estado em áreas consideradas estratégicas pela esquerda.

Por mais que o PSDB fosse considerado mais à esquerda que o PMDB, por ser mais progressista e ter sido criado a partir de discórdias ocorridas no próprio PMDB, os estudos realizados por Roma (2002) e Guiot (2006) apontam para outro caminho. Desde sua criação até as alianças realizadas para a eleição presidencial de 1994, como a coligação com o PFL, os documentos do partido e suas políticas mostram que o PSDB esteve sempre mais próximo do campo da centro/direita do que da esquerda ${ }^{18}$.

\section{O "peso" do Plano Real e a dinâmica do HGPE na eleição de 1994}

Desde a década de 1970 até o ano de 1994, com a última etapa da implementação do Plano Real (mais especificamente com a implementação da moeda "Real"), a inflação era um dos principais problemas da economia brasileira (Bresser-Pereira, 2010, p. 168). Somente no final da década de 1980 e início da de 1990 foram realizados cinco planos econômicos que não obtiveram o sucesso esperado: Planos Cruzado (1986), Bresser (1987), Verão (1989), Collor I (1990) e Collor II (1991). Apontada como um dos principais problemas do insucesso dos Planos, a inflação inercial ${ }^{19}$ passou a ser interpretada como resultante do desequilíbrio econômico do próprio Estado brasileiro e da baixa distribuição de renda.

\footnotetext{
16 O PFL sempre foi visto como um partido de direita, pois sempre defendeu uma política voltada para um modelo de economia liberal. Suas bases são oriundas do PDS (Partido Democrático Social), antiga Arena (Aliança Renovadora Nacional), partido que fez parte da ditadura militar. Após 1990, o que mais caracteriza um partido conservador são suas políticas voltadas para o mercado, abertura ao capital estrangeiro, redução dos gastos públicos e privatizações (Mainwaring, Meneguello e Power, 2000).

17 Para mais informações, ver o Estatuto do PSDB (Estatuto PSDB, 2011).

18 Para outras informações sobre o PSDB, ver Vogel (2013).

19 A inflação inercial pode ser definida, grosso modo, como aumentos assincrônicos de preços tanto pelos agentes produtivos como por parte dos agentes distributivos e consumidores (Bresser-Pereira, 2010, p. 178).
} 
No ano de 1993, o ministro das Relações Internacionais, FHC, foi convidado pelo então presidente da República, Itamar Franco (PMDB), para assumir o Ministério da Fazenda com a função de desenvolver e executar um novo plano econômico com o principal objetivo de controlar a inflação. Assim, em agosto de 1993, começava a ser implementado o Plano Real20. Num primeiro momento, definido como "fase preliminar" (Souza, 2012, p. 41), o Plano, visando o controle da inflação, apontava a necessidade de cortes nos gastos públicos, privatizações e aumento de impostos, o que gerou certa apreensão por parte significativa do Legislativo, tendo em vista a proximidade das eleições. Contrariando essa expectativa, muito em virtude da grande propaganda e publicidade realizada em torno do Plano, o que ajudou sobremaneira na adesão popular e na confiança em seus resultados, os acordos políticos tornaram a implementação do Plano Real viável "eleitoralmente". Com as fases seguintes, desde a criação da Unidade Real de Valor (URV) ${ }^{21}$ até a efetivação da moeda "Real", a publicidade e a articulação política realizada pela equipe de FHC foram pontos centrais para o sucesso do Plano no campo político. Do ponto de vista do eleitorado, que respaldou as decisões tomadas no Legislativo e acalmou o campo político, a segunda etapa do Plano Real, que foi a troca da moeda e controle da inflação de forma abrupta, daria o tom da campanha eleitoral que começava (Mendes e Venturi, 1994, p. 60).

O Plano Real, efetivado durante o processo eleitoral, acabou sendo o principal "elemento político" na eleição presidencial de 1994. Um ano antes da referida eleição, o candidato do PT, Lula, aparecia à frente nas pesquisas de intenção de voto. O mesmo quadro de intenção de voto se mantinha até o primeiro quadrimestre de 1994, com pequenas variações (Mendes e Venturi, 1994, p. 61). Ainda com o cenário econômico instável e sem saber se o Plano Real surtiria o efeito esperado, FHC, em março de 1994, decide deixar a base do governo Itamar, indicando que seria candidato à presidência da República (Souza, 2012, p. 43). Com a implantação da moeda "Real", em agosto de 1994, e o início oficial das campanhas eleitorais e, posteriormente, com o HGPE, em que o candidato peessedebista se coloca como o criador do "Real", as pesquisas de intenção de voto já apontavam FHC à frente de Lula (Mendes e Venturi, 1994, p. 62). É mais que evidente que o Plano Real, e seus efeitos positivos na economia, sentidos a partir da implantação da moeda "Real", foi o responsável por essa virada nas pesquisas (Souza, 2012, p. 54).

Tema central no contexto político-social e refletido no processo eleitoral após outubro de 1994, o controle da inflação por meio do Plano Real e da nova moeda foram os elementos discursivos decisivos na mudança de intenção de voto e que constitui discursos antagônicos. Por esse motivo, o Plano assumiu um protagonismo durante o HGPE, considerado por Souza (2012) como tema hegemônico entre as candidaturas. Como já

20 Para mais informações, ver Exposição de Motivos (Brasil, 1994). Disponível em: <http://www2.camara.leg.br/legin/fed/medpro/1994/medidaprovisoria-542-30-junho-1994-375071norma-pe.html>. Acesso em: 2 ago. 2018. Para outras informações e interpretações, ver Ianoni (2009).

${ }^{21}$ Para mais informações sobre URV e seus desdobramentos, ver Bresser-Pereira $(1994,2010)$. 
destacado, esse reconhecimento do Plano e da candidatura do peessedebista FHC se deu principalmente com início do HGPE, quando o candidato tucano se coloca como o criador do Plano (o "pai" do Real). As intenções de voto apontaram a identificação do Plano com FHC, bem como sua continuidade, como destacou Mendes e Venturi (1994, p. 65-66), a principal razão para o voto no peessedebista.

O HGPE, por se tratar de um espaço específico de propaganda e de disputa eleitoral com suas características próprias (Figueiredo et al., 2000; Figueiredo e Aldé, 2003), mesmo que relacionadas com outros campos, como a mídia de modo amplo (Biroli e Miguel, 2013), necessita, por parte das candidaturas, de estratégias visando conquistar o voto do eleitor. Além dos caminhos metodológicos desenvolvidos e aplicados por Figueiredo et al. (2000) e replicados por Figueiredo e Aldé (2003) com o objetivo de identificar as estratégias "discursivas" das "candidaturas" em campanhas eleitorais majoritárias e seus efeitos na intenção de voto, buscamos trazer ao debate e apresentar neste artigo que a dimensão do antagonismo e seus efeitos de desconstrução discursiva indicam um novo caminho e um renovado olhar sobre essas estratégias de campanhas. Olhando o contexto político-eleitoral no momento em que era escrito este artigo (outubro de 2018), a eleição para presidente da República de 2018, percebe-se que sentidos antagônicos e de disputa sobre realidades passadas e futuras estão em jogo quando verificamos as posições adotadas pelas candidaturas de PT (Fernando Haddad), PSDB (Geraldo Alckmin), PDT (Ciro Gomes) e REDE (Marina Silva), buscando desconstruir a "imagem discursiva" (no sentido laclauniano, como tratado neste artigo) da candidatura do PSL (Jair Bolsonaro). Coloco como candidaturas, pois, ainda mais nesse contexto específico, a relação de sentidos entre o candidato a presidente Jair Bolsonaro e seu vice, General Mourão, indica, conforme uma rápida e superficial análise ${ }^{22}$, a condensação de uma hegemonia ultrarradical e com fortes traços antidemocráticos.

Retomando o foco deste artigo, após uma rápida digressão com o intuito de ampliar o campo de reflexão, recordamos que, pela conjuntura política, econômica e eleitoral que se criou no contexto da eleição para presidente da República de 1994, já era de esperar que o Plano Real assumisse centralidade no debate e nas disputas políticas que viriam a ocorrer, principalmente entre as duas principais candidaturas que despontavam antes e durante as eleições. Uma de oposição ao governo, representada por Lula, e outra não como continuidade do governo peemedebista, mas sim de continuidade do Real, representada por FHC.

O HGPE foi instituído no Brasil no ano de 1962 com o objetivo de criar um espaço democrático para que os candidatos pudessem divulgar suas propostas durante o momento das campanhas eleitorais. Após o golpe militar em 1964, o governo ditatorial passou a utilizar práticas que tinham como objetivo favorecer apenas a sua posição, constituindo

22 Informação disponível em: <https://www1.folha.uol.com.br/mercado/2018/08/bolsonaro-representarisco-a-democracia-escreve-the-economist.shtml>. Acesso em: 4 ago. 2018. 
uma clara descaracterização de seu objetivo; por exemplo, a Lei Falcão23. No ano de 1985, com a transição para a redemocratização no Brasil, a responsabilidade da organização do HGPE passou a ser do Tribunal Superior Eleitoral (TSE), tornando-se mais um elemento importante para o formato de propaganda pretendido para esse novo modelo democrático.

Para as eleições de 1994 alguns pontos causaram polêmicas. Passou a ser proibida a utilização de imagens produzidas fora dos estúdios de gravação, bem como a utilização de montagens com imagens que não identificasse o candidato e o partido em questão.

Art. 76. Os programas destinados à veiculação no horário gratuito pela televisão devem ser realizados em estúdio, seja para transmissão ao vivo ou pré-gravados, podendo utilizar música ou jingle do partido, criados para a campanha eleitoral.

$1^{0}$ Nos programas a que se refere este artigo, é vedada a utilização de gravações externas, montagens ou trucagens.

OBS 1: Entende-se por trucagem todo e qualquer efeito realizado em áudio ou vídeo que degradar ou ridicularizar candidato, partido político ou coligação, ou que desvirtuar a realidade e beneficiar ou prejudicar qualquer candidato, partido político ou coligação.

OBS 2: Entende-se por montagem toda e qualquer junção de registros de áudio ou vídeo que degradar ou ridicularizar candidato, partido político ou coligação, ou que desvirtuar a realidade e beneficiar ou prejudicar qualquer candidato, partido político ou coligação (Lei no 8.713 , de 30 de setembro de $\left.1993^{24}\right)$.

Para essa eleição, as emissoras de rádio e de televisão deveriam reservar, em sua programação, duas horas diárias para a propaganda eleitoral gratuita, sendo uma hora para a eleição presidencial que deveria ser transmitida aos domingos, às segundas, às quartas e às sextas, com início 60 dias antes da antevéspera das eleições. A propaganda eleitoral no rádio e televisão era restrita ao horário gratuito, vedada a veiculação de propaganda paga. A veiculação de propaganda com vistas à eleição presidencial foi feita em cadeia nacional, das $7 \mathrm{~h}$ às $7 \mathrm{~h} 30$ e das $20 \mathrm{~h} 30$ às $21 \mathrm{~h}$ na televisão, e das $7 \mathrm{~h}$ às $7 \mathrm{~h} 30 \mathrm{e}$ das $12 \mathrm{~h}$ às $12 \mathrm{~h} 30$ no rádio - conforme a lei no 8.713, de 30 de setembro de 1993 (Brasil, 1993).

A divisão do tempo para cada candidato/partido/coligação que concorria à presidência da República na eleição de 1994 ficou definida da seguinte forma:

Art. 74. A Justiça Eleitoral distribuirá o tempo em cada um dos períodos diários do horário reservado à propaganda eleitoral gratuita entre os partidos e

\footnotetext{
23 Para uma leitura mais detalhada, ver Fleischer (1994).

24 Todas as informações referente à lei eleitoral vigente na eleição de 1994 podem ser encontradas em: <http://www.planalto.gov.br/CCivil_03/Leis/L8713.htm>. Acesso em: 15 out. 2018.
} 
coligações que tenham candidato a cada eleição de que trata esta lei, observados os seguintes critérios:

I - na eleição presidencial:

a) dez minutos divididos igualitariamente entre os partidos e coligações;

b) vinte minutos divididos proporcionalmente ao número de representantes de cada partido ou coligação na Câmara dos Deputados (Lei no 8.713, de 30 de setembro de 1993) (Brasil, 1993).

Com a distribuição do tempo de televisão destinado ao HGPE nas eleições de 1994, a candidatura do PSDB, com a coligação PSDB, PFL e PTB ${ }^{25}$ (o candidato a vice-presidente dessa chapa foi Marco Maciel, indicação do PFL), ficou com 7 minutos e 49 segundos - 0 maior tempo de exposição no HGPE. Ao conquistar um espaço significativo na grande mídia com o sucesso do Plano Real, e com a oposição do PT, FHC buscou fazer novas alianças políticas para a eleição. Isso teve impacto em seu tempo de exposição no HGPE. Como já mencionado, nessa eleição o partido demonstrou uma nova abertura em relação a suas alianças políticas. Antes considerado de esquerda, pelo menos em sua origem (Roma, 2002; Motta, 2008), e que construía sua base nesse mesmo espectro político, nas eleições de 1994 essa configuração ideológica apresentou alterações significativas. Nesse sentido, a aliança feita com o PFL e o PTB, partidos classificados como de direita (Mainwaring, Meneguello e Power, 2000), indica essa mudança articulatória do partido (Roma, 2002).

Lula, principal adversário de FHC nessa disputa, tinha como vice Aloizio Mercadante, também do PT. A coligação composta por PT, PPS ${ }^{26}$, PSB, PCdoB ${ }^{27}, \mathrm{PV}^{28}$ e PSTU29 ficou com 3 minutos e 31 segundos de programação, apenas o quarto maior tempo de exposição. Nessa eleição pôde-se perceber que as alianças realizadas pelo PT se mantiveram no campo da esquerda. Mesmo formando uma aliança mais numerosa que seu principal adversário, composta por seis partidos, o seu tempo de exposição no HGPE ficou menor, pois tais partidos constituíam representação menos expressiva no Congresso Nacional.

Esses tempos foram referentes aos primeiros nove programas de cada candidatura, pois, com a renúncia de Flávio Rocha, do $\mathrm{PL}$, o tempo desse candidato foi redistribuído entre todos os concorrentes. Desse modo, nos 23 programas restantes do primeiro turno, a candidatura do PSDB aumentou seu tempo para 8 minutos e 10 segundos, e a do PT para 3 minutos e 45 segundos.

Lula ficou atrás, no tempo de exposição no HGPE, de Orestes Quércia (PMDB), com 6 minutos e 15 segundos (depois com 6 minutos e 30 segundos) e de Esperidião Amin, do Partido Progressista Reformador (PPR), com 4 minutos (depois com 4 minutos e 12

\footnotetext{
25 Partido Trabalhista Brasileiro (PTB).

26 Partido Popular Socialista (PPS).

27 Partido Comunista do Brasil (PCdoB).

28 Partido Verde (PV).

29 Partido Socialista dos Trabalhadores Unificado (PSTU).
} 
segundos). Quércia e Amin terminaram as eleições como quarto e sexto colocados, respectivamente. Após a apresentação desse panorama, nas próximas duas seções serão apresentados os discursos das candidaturas de PSDB e PT tratando do Plano Real, bem como seus sentidos antagonicamente constituídos.

\section{O Plano Real no discurso do PSDB}

Durante a campanha presidencial do PSDB em 1994, o Plano Real assumiu um "protagonismo" no que se refere às disputas políticas pelos seus sentidos, ou seja, foi o tema, dentre todos os abordados, que possibilitou a emergência dos discursos antagônicos. Nesta seção serão apresentados os sentidos e os momentos na formação da cadeia discursiva da campanha eleitoral de FHC, tratando do Plano Real - ponto antagônico entre os discursos das candidaturas de PSDB e PT nesse contexto específico. Para isso foram transcritos ao todo 30 programas eleitorais do PSDB veiculados durante o HGPE na eleição de 1994, o que representa sua totalidade - não repetidos. Deste total, de forma direta ou relacionada a outro tema, 11 abordaram o tema "Plano Real". Então, o tema Plano Real, ponto antagônico entre as candidaturas, ocupou mais de um terço dos programas peessedebistas, o que corresponde a $36,66 \%$ dos programas do referido ano.

A partir da identificação da regularidade em torno do Plano Real como tema sistematizador da relação antagônica entre as candidaturas de PSDB e PT nas eleições de 1994, foi possível, com base nos pronunciamentos de campanha da candidatura do PSDB, distinguir três fluxos argumentativos: "combate à inflação", "mudanças positivas com o Real" e "manutenção do Real". A relação entre elementos discursivos produzidos nesse campo da discursividade apresentou sentidos que iam em direção de algum desses fluxos, o que, a partir de certas regularidades argumentativas, passou a ser identificado como momentos discursivos; momentos carregados de sentidos em relação aos próprios momentos, bem como na estruturação do próprio discurso da candidatura peessedebista sobre o Plano Real: "Plano Real: a conquista da estabilidade econômica".

\section{Momento 1: Combate à inflação}

Um dos primeiros sentidos relacionados ao Plano Real foi o de "cuidar dos brasileiros", como podemos perceber no trecho que segue:

FHC: A primeira solução para mudar o Brasil e cuidar dos brasileiros é o combate à inflação. Este passo está sendo dado. Quando eu fui para o Ministério da Fazenda, eu disse que a inflação iria ser controlada, e ela está sendo controlada. O custo de vida parou de subir, a população está pechinchando e os preços estão sendo levados para baixo. O povo, como sempre, está fazendo sua parte. Eu espero que os empresários e os 
comerciantes também façam a parte deles. É hora de todos pensarmos no Brasil. Chegou a hora do povo ganhar. Aliás, o cidadão comum, a dona-decasa, eles perceberam primeiro que muitos políticos que este Plano é de verdade, que esse Plano é coisa séria, e que ele vai funcionar. Nós podemos mudar este país, mas não com raiva, com radicalismo. Nós podemos mudar juntos. O primeiro passo foi dado, agora precisamos dar outros passos. E a você, que acreditou em mim, eu peço que continue acreditando, porque nós vamos enfrentar as mesmas pressões e incompreensões que a equipe econômica enfrentou para pôr em prática o Plano Real (Programa Eleitoral FHC/PSDB, HGPE, 5/8/1994).

O Plano Real é identificado no pronunciamento do candidato FHC como sendo o projeto capaz de combater a inflação, o que habilitaria o candidato a cuidar dos brasileiros. Além disso, segundo o excerto acima, o combate à inflação promovido pelo Plano Real atenta para o fato de que todos que estejam envolvidos com o seu resultado - a sociedade de modo geral -, devem pensar no Brasil para que o Plano obtenha sucesso. Nessa passagem ficam claros os primeiros sentidos atribuídos ao Plano e seu papel na luta contra a inflação: sem inflação o povo e os trabalhadores ganham e todos pensando no Brasil.

No tocante às vantagens que o povo teria com o Plano e o papel desse novo projeto econômico em relação à luta contra a inflação, o ponto geração de emprego aparece intimamente ligado a esse aspecto do discurso da candidatura peessedebista, como podemos perceber na fala do próprio candidato:

FHC: Para poder criar novos empregos foi preciso arrumar a economia, acabar com a inflação, valorizar a moeda. Fazer do povo a prioridade número um e fazer a economia funcionar para gerar mais emprego e botar mais dinheiro no bolso dos trabalhadores. E como é que se faz isso? Nós já começamos a fazer. O Plano Real é um passo importantíssimo nesse sentido. Mas é preciso fazer muito mais. (...). Com o fim da inflação, não vale mais a pena para o empresário deixar o dinheiro parado no banco. Este dinheiro, agora, para render, tem que ser aplicado em setores produtivos ampliando a produção, abrindo novas fábricas e, com isso, gerando novos empregos (Programa Eleitoral FHC/PSDB, HGPE, 10/8/1994).

A geração de emprego, conforme o discurso de campanha de FHC, depende da estabilidade econômica e do controle da inflação. Como veremos na seção que trata do discurso da candidatura do PT, tal afirmativa não é o que evidencia a relação antagônica entre as candidaturas do PSDB e do PT, tendo em vista que ambos concordam que uma economia estável e uma inflação baixa são fundamentais para a geração de novos empregos, mas a relação antagônica está instituída na forma como a política de combate à inflação estava sendo implementada pelo governo de que FHC fazia parte. Ainda conforme a passagem acima, com a estabilidade da economia e com o fim da inflação, a 
tendência seria um maior investimento na produção por parte dos empresários. Portanto, uma série de elementos dispersos passa a gerar sentidos em relação ao Plano Real, como, por exemplo, o aumento do poder aquisitivo. Além disso, pode-se verificar que entre esses elementos e sentidos apresentados existe algo em comum que vai ao encontro da importância de controlar a inflação.

Em relação ao poder aquisitivo/poder de compra e aos baixos salários, ambos são atribuídos à alta inflação:

FHC: Vamos falar a verdade, o salário do trabalhador brasileiro está baixo, muito baixo. Quem depende de salário não vive, sobrevive. E isso não é de hoje. Não dá para fazer quase nada com o salário que se ganha. Sustentar a família, dar roupas para os filhos, pagar transporte, comprar remédios, nada. E todo mundo vive me perguntando, por que o trabalhador ganha tão mal? A inflação é a grande culpada pelos salários baixos. A inflação sempre derrotou todas as greves em busca de melhores salários. $O$ aumento que se conseguia num dia, no outro a inflação comia. Agora, com a nova moeda, o real, o salário parou de perder da inflação. Com os preços estabilizados, os salários estão ganhando poder de compra (Programa Eleitoral FHC/PSDB, HGPE, 12/8/1994).

Num pronunciamento amplo proferido por FHC, podemos verificar vários elementos que atribuem sentido ao Plano Real e que condensam o entendimento de combate à inflação:

FHC: Durante muitos anos o Brasil criou um monte de bichos de sete cabeças. Uns como a reforma agrária, o aumento do salário mínimo, a distribuição de renda, a reforma da previdência, a educação de boa qualidade, coisa que durante anos e anos as pessoas rotularam impossível, que não dava para fazer, que não tinha solução. Pois essas coisas são tão possíveis de serem feitas, como foi possível baixar a inflação, que nós fizemos. E sabe por quê? Porque nós fizemos conversando, e os outros quiseram fazer na marra. Tem gente no Brasil que gosta de dizer que as coisas são complicadas para que as soluções pareçam radicais. Não precisa nada disso. O que o Brasil precisava era estabilidade. Com os preços subindo todo dia, você não conseguia governar o seu salário. A dona de casa não conseguia governar a sua casa. E ninguém conseguia governar esse país. Agora é diferente, nós começamos a ter estabilidade, a ter sucesso. E agora podemos fazer um plano social para melhorar a vida das pessoas, para consertar a saúde, para melhorar a educação, para fazer a reforma agrária, para encontrar solução para os problemas da previdência, para gerar mais empregos para quem precisa. Se alguém the disser que tudo isso é impossível, você sabe que não é, não é verdade. Com o Plano Real nós fizemos a primeira coisa que os outros diziam 
ser impossível, nós acabamos com o primeiro bicho de sete cabeças (Programa Eleitoral FHC/PSDB, HGPE, 9/9/1994).

Segundo o excerto acima, com a estabilidade econômica e o controle da inflação, possibilitados pelo Plano Real, o plano social, a saúde, a educação, a reforma agrária, a reforma da previdência e a geração de emprego se tornariam possíveis. Contrariando os pessimistas - uma crítica aos seus adversários - que não acreditavam que o Real controlaria a inflação, traria a estabilidade econômica e possibilitaria as reformas necessárias, FHC expõe que o primeiro "grande bicho de sete cabeças" tinha sido combatido e que os eleitores podiam acreditar que, combatida a inflação, as reformas seriam feitas (no geral, melhoraria a vida dos brasileiros). Dessa forma, novos elementos dispersos nesse campo da discursividade produzem sentidos a partir do Plano Real e no entendimento da importância de combater a inflação e seu reflexo para a estrutura social.

Momento 2: Mudanças positivas com o Real

Todos os sentidos atribuídos ao momento "combate à inflação" estavam interligados não só pelo momento discursivo, mas pelo próprio discurso que foi sendo constituído em relação ao Plano Real a partir da candidatura do PSDB. O aumento do poder aquisitivo com o controle da inflação reapareceu no campo da discursividade, gerando outros sentidos; nesse instante, tal sentido se referia às mudanças positivas proporcionadas pelo Plano Real. Nessa perspectiva, o "aumento do salário mínimo" e "criar melhores condições de trabalho" apareciam como pontos positivos que o Real já pôde proporcionar de imediato:

FHC: Durante meu governo eu pretendo dobrar o valor do salário mínimo. Hoje ele é de 70 reais, e eu garanto que ele chegará a 140. Eu pretendo assegurar a livre negociação e contrato coletivo para que o trabalhador defenda não só os seus salários, mas também melhores condições de trabalho. E pretendo sancionar a lei que regulamenta a participação dos funcionários nos lucros das empresas. A mudança começou com o Plano Real, mas ela vai continuar para colocar cada vez mais as pessoas em primeiro lugar (Programa Eleitoral FHC/PSDB, HGPE, 12/8/1994).

Tais mudanças, segundo os sentidos produzidos pela candidatura do PSDB, já podiam ser percebidas a partir da implantação do Plano Real. Com o Plano e com as primeiras melhorias, o Brasil encontrava um caminho para continuar a realizar as mudanças que o Real propiciava:

FHC: Qualquer pessoa que vive de salário e que esteja observando o Brasil, vê que tendo apenas 60 dias de tranquilidade, de sucesso, vê que muita coisa boa começa a acontecer. Eu não estou dizendo que tudo ficou uma maravilha 
de uma hora para outra, num passe de mágica. Só que agora, além dos problemas, o Brasil tem um caminho, tem um rumo. E nesses 60 dias, nós já caminhamos bastante. $O$ preço da cesta básica começou a diminuir, a taxa de desemprego também, a venda dos produtos populares aumentou, as vendas pelo crediário aumentaram, porque agora todo mundo já sabe como vai ser o mês seguinte. As pessoas lembram-se dos preços das coisas. A dona de casa não precisa correr ao supermercado para fazer estoques. Os pais de família podem planejar o mês. É disso que o Brasil precisa! Estabilidade (Programa Eleitoral FHC/PSDB, HGPE, 24/8/1994).

Tais elementos mostram o sentido de que o Plano Real conseguiu produzir melhorias de imediato na vida das pessoas a partir da política econômica adotada, bem como na estruturação da nova moeda, o Real.

Numa outra passagem, o candidato fazia menção à preocupação que as pessoas tinham com o Real, indicando as conquistas possibilitadas com o Plano e com a moeda. Elementos dispersos como queda dos preços nos supermercados, maior poder de compra e aumento do valor real da moeda geravam sentidos que estariam ligados diretamente ao entendimento de que o Plano Real possibilitou melhorias consideráveis à vida das pessoas:

FHC: Frequentemente as pessoas me perguntam: como vai o real? Eu respondo: vai bem. Você vê que os preços nos supermercados estão parados ou caindo desde o começo do plano, desde o começo de julho. E isso significa maior poder de compra no seu bolso, porque o seu dinheiro vale mais. As pessoas perguntam: e a inflação? A inflação está caindo, a carestia está sendo derrotada. Até 15 de junho, antes do Real, a inflação foi de $48 \%$. Hoje, ela caiu para cerca de $5 \%$. E as projeções, até o final de agosto, apontam índices ainda mais baixos, segundo os especuladores. Daqui para frente, os próximos índices de inflação deverão cair ainda mais, porque cada vez mais diminuirão os efeitos dos aumentos irresponsáveis feitos na véspera do Real (Programa Eleitoral FHC/PSDB, HGPE, 2/9/1994).

A relação entre esses elementos indica a formação de um entendimento de que o Plano Real possibilitou mudanças positivas na sociedade como um todo. Nesse mesmo sentido, FHC afirmou:

FHC: $\mathrm{E}$ eu vou criar condições para que a iniciativa privada invista mais de 40 bilhões de reais nos próximos 4 anos. E isso vai gerar, no mínimo, 4 milhões de novos empregos. O Plano Real é só o começo das mudanças. Esse país vai mudar pra valer (Programa Eleitoral FHC/PSDB, HGPE, 10/8/1994).

Era criado, a partir da fala do próprio candidato, um panorama futuro de mudanças ainda melhores. Segundo a candidatura tucana, as mudanças positivas possibilitadas pelo 
Plano Real seriam apenas o início. Dessa maneira, novos elementos geraram sentidos a partir das melhorias possibilitadas com o Real.

Assim, o segundo momento do discurso antagonicamente construído na candidatura do PSDB na eleição de 1994 ficou simbolizado a partir da ideia de "mudanças positivas com o Real".

\section{Momento 3: Manutenção do Real}

A relação estabelecida entre elementos dispersos a partir dos sentidos gerados quanto à ideia de manutenção do Real, contidos nos pronunciamentos da candidatura do PSDB na eleição de 1994, direciona para formação do terceiro momento do discurso das candidaturas tucanas. Como ocorreu na estruturação dos momentos anteriores, alguns elementos reaparecem indicando sentidos diferentes, porém não contrários.

Logo, os sentidos que constituem esse momento também dialogam com os outros momentos já apresentados. Isso pode ser percebido a partir do seguinte trecho:

FHC: O Plano Real não vai resolver todos os nossos problemas em 2 ou 3 meses. O mal do Brasil, e dos outros planos, sempre foi o imediatismo. Por isso, será preciso vigiar o andamento do Plano Real e, se necessário, fazer os ajustes no futuro para que ele continue dando certo. (...). Sabemos que será preciso tomar medidas para garantir a continuidade do Real. (...). Você é o primeiro aliado que o Real precisa. Defenda o Real com seu voto. Vote nos candidatos a deputados, a senador e a governador que defendam o Real. Não apenas que estão defendendo agora, quando viram que o povo vota a favor do Real, que perderiam votos ficando contra. Vote nos que defenderam o Plano desde o começo. O Real é o início da mudança, é ele que vai tornar possível o plano social para colocar as pessoas em primeiro lugar (Programa Eleitoral FHC/PSDB, HGPE, 2/9/1994).

A "manutenção do Real", além de ser caracterizada como um plano de longo prazo e de ter o eleitor como seu aliado forte, garantia que o projeto social proposto por FHC e seu partido fosse posto em prática. Ainda, o trecho exibido no programa eleitoral pedia para os eleitores que apoiavam o Real para votarem nos candidatos a outros cargos que também apoiassem o Real; defendendo o Real com o próprio voto. Novos sentidos emergem quando FHC responde de forma direta às críticas feitas pelo seu principal oponente, Lula:

FHC: Uma das grandes preocupações que eu sinto quando viajo pelo Brasil, é uma coisa que me pergunto: se o Plano Real não é uma coisa eleitoreira, que vai ser deixado de lado logo depois das eleições? Eu posso falar por mim. Se eu ganhar as eleições, não. Porque é justamente um dos motivos que me 
fazem concorrer para Presidente é garantir que o Plano Real continue (Programa Eleitoral FHC/PSDB, HGPE, 5/8/1994).

As afirmações de FHC, em certa medida respondendo às críticas feitas por Lula, indicam que o Plano Real não se caracterizava como eleitoreiro, evidenciado quando FHC afirma que sua eleição servirá exatamente para "garantir a continuidade do Real", criando certo sentimento de incerteza quanto à manutenção do Plano nas mãos de seus opositores - uma referência ao seu principal concorrente, Lula. Criando esse sentimento, FHC apela para uma retórica de manutenção do Real, que, como já foi indicado nos outros momentos do discurso produzido pela sua campanha, é em benefício do povo. "FHC: Minhas ideias são as ideias do povo, que quer a casa em ordem. O nosso empenho é garantir o futuro do Plano Real, que não pertence a ninguém, que pertence ao Brasil. O Plano é bom, e o povo está do lado dele" (Programa Eleitoral FHC/PSDB, HGPE, 09/09/1994).

Nesse mesmo sentido, sobre as melhorias que o Real possibilitou, mas, sobremaneira, sobre a necessidade de sua manutenção para que o povo também melhorasse:

FHC: Olha quanta coisa boa está acontecendo só porque o povo está podendo consumir. E olha que são apenas 60 dias de melhora. (...). Um país como o nosso pode tudo se cuidar do seu povo. O povo é a grande saída. Por isso o Plano Real é tão importante. Por que colocando a economia em ordem, criando estabilidade com uma moeda forte, é possível dar os passos seguintes, que é a reforma tributária, a reforma da constituição e as reformas sociais. Feito isso, ninguém detém o Brasil. $O$ Real é o primeiro passo para nossa independência da miséria, da fome e da ignorância (Programa Eleitoral FHC/PSDB, HGPE, 7/9/1994).

Os elementos descritos no excerto acima geram sentidos na direção da manutenção do Real. Retomando as críticas feitas ao seu principal adversário, Lula, e se referindo às incertezas sobre a continuidade do Real caso Lula ganhasse as eleições, o programa peessedebista apresentava a seguinte informação:

Locutor: No seu último programa, nosso principal adversário gastou todo seu tempo atacando Fernando Henrique. Não fez uma única proposta, não atacou nenhum problema. Foram 3 minutos e 45 segundos desperdiçados. Imaginem se fossem 4 anos. (...) Nestas eleições, você vai decidir se o Plano Real vai continuar ou não. Se o Brasil vai passar os próximos 4 anos procurando soluções, ou procurando culpados. Nestas eleições, você vai decidir se vamos ter um governo a favor ou contra (Programa Eleitoral FHC/PSDB, HGPE, 2/9/1994).

Criando um sentimento de "medo" em relação às ações de Lula e de seu possível governo ao se referir à continuidade do Real, o locutor faz uma separação clara de quem 
dará continuidade ao Plano e de quem acabará com ele. Diversos elementos apresentados no pronunciamento da candidatura tucana indicam a relação que FHC e seu partido tinham com o Plano, fazendo uma separação entre seus verdadeiros defensores e os "inimigos do Real". Destarte, a relação entre tais elementos desenvolve sentidos que passam pela ideia de que a manutenção do Real dependia da vitória de FHC.

Isso feito, podemos perceber o terceiro momento do discurso antagonicamente construído na candidatura do PSDB na eleição de 1994, simbolizado a partir da ideia de "manutenção do Real" como estruturante do discurso da candidatura peessedebista.

\section{Plano Real: A conquista da estabilidade econômica}

A campanha político-eleitoral de FHC em 1994, veiculada no HGPE, colocou o Plano Real como o elemento fundamental para retirar o Brasil da instabilidade econômica causada pela hiperinflação e como o passo primário para que o país pudesse "cuidar" dos brasileiros. Nesse sentido, primeiro era preciso estabilizar a economia e controlar a inflação para depois pensar em outras políticas. A partir da regularidade de elementos e dos sentidos gerados nesse processo de regularidade, ficou caracterizada a defesa do Plano por parte da candidatura peessedebista.

O primeiro momento identificado foi "combate à inflação". Nesse momento discursivo, o principal ponto defendido foi o de que o Plano Real seria a saída para controlar a inflação e manter a estabilidade econômica, altamente ligada, conforme os pronunciamentos da candidatura tucana, ao próprio combate à inflação. O segundo momento percebido foi "mudanças positivas com o Real". O principal ponto defendido aqui foram as conquistas que o Plano Real possibilitou. Como já argumentado, mas importante retomar, elementos dispersos foram percebidos, a partir de seus sentidos, ligados a outro momento. Isso quer dizer que ocorreu a produção de sentidos diferentes a partir de sua similaridade, mesmo que não contraditórios e nem opostos. O terceiro momento detectado foi "manutenção do Real". Nesse momento, o principal ponto constituído nos pronunciamentos da candidatura do PSDB informava a importância de dar continuidade no Plano Real, e apresentava FHC como o candidato ideal para tal projeto político.

Compreendida a estruturação dos momentos e seus sentidos, foi identificada nos pronunciamentos da candidatura tucana a recorrência argumentativa em torno do Plano Real que, organizada a partir dos momentos "combate à inflação", "mudanças positivas com o Real" e "manutenção do Real", constituiu o ponto nodal "Plano Real: a conquista da estabilidade econômica". A Figura 1 apresenta de forma sistematizada e organizada a formação do discurso da candidatura do PSDB, tendo em vista sua relação antagônica com o da candidatura do PT, que será apresentada na próxima seção. O ponto nodal e os momentos representativos da relação antagônica também são identificados a partir desse discurso sistematizador, como mostra a Figura 1. Em virtude disso, e em se tratando do 
objetivo deste artigo, o ponto nodal, a instauração do antagonismo, é o que caracteriza o discurso da candidatura supracitada:

Figura 1

Discurso da candidatura do PSDB na eleição de 1994

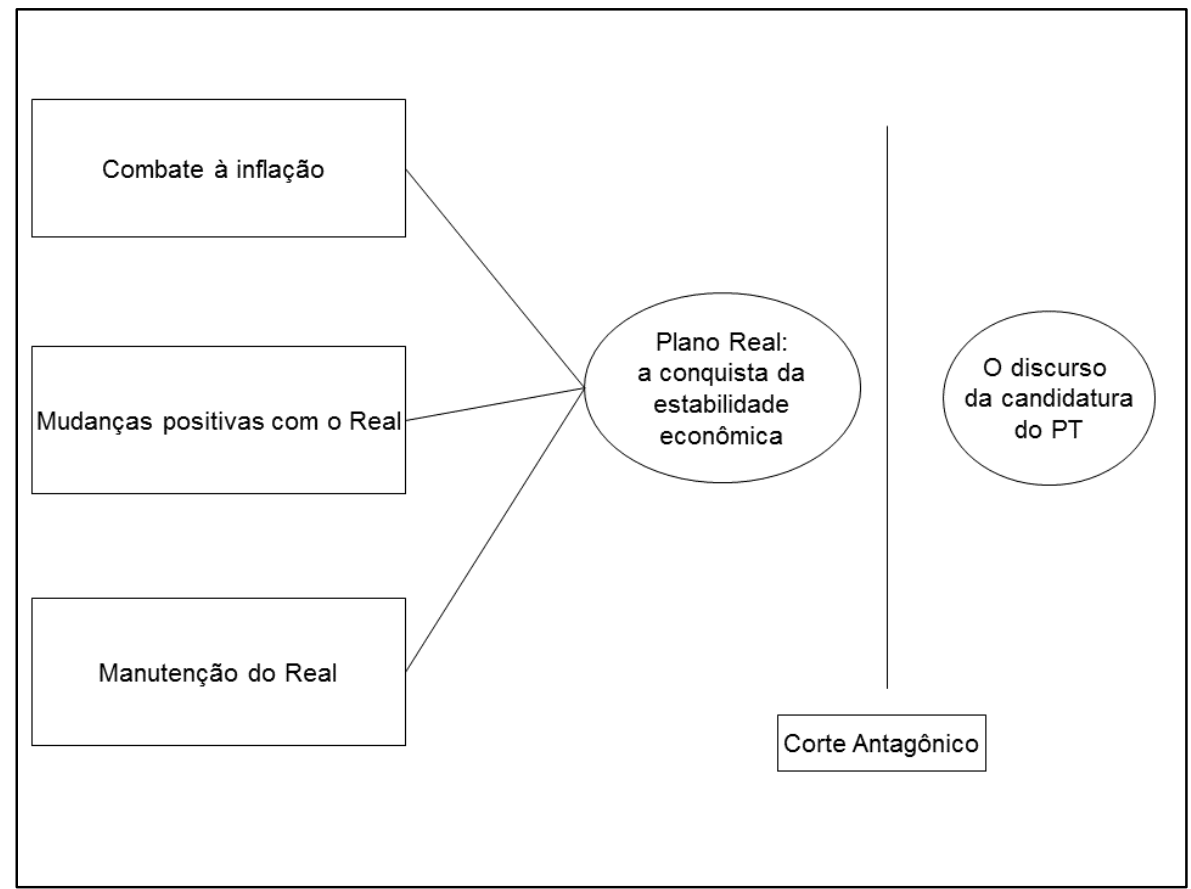

Fonte: Elaborado pelo autor a partir dos programas veiculados no HGPE (1994).

Realizada a apresentação da formação do discurso de FHC na campanha à presidência da República na eleição de 1994, é possível perceber que os momentos discursivos apresentaram uma gama de sentidos que sustentaram o discurso de "defesa" do Plano Real. Como veremos na seção seguinte, o discurso de campanha do candidato petista se constituiu quase que em resposta às afirmações feitas nos programas eleitorais de FHC. No decorrer disso, o diálogo antagônico entre os programas dos candidatos se estendeu, levando FHC a responder a determinadas críticas apresentadas no programa de seu principal oponente.

Alguns sentidos, como a "esperança no Plano" e a "política do medo", também foram identificados de forma direta ou indireta por Amaral (1995), Jorge (1995), Almeida (1998), Porto e Guazina (1999), Oliveira (2005) e Souza (2012). Identificamos, além dos achados dos autores, que tais sentidos se constituíram por meio de disputa discursiva antagônica e que formaram os momentos do discurso da candidatura do PSDB, estabelecendo mais um elemento de reflexão e decisão do voto. Nas conclusões retomaremos esses aspectos. 


\section{O Plano Real no discurso do PT}

Como ventilado na seção anterior, entre os temas abordados durante os programas eleitorais do PSDB e do PT veiculados no HGPE durante as eleições de 1994, foi o Plano Real o ponto nodal da disputa antagônica instituída entre as candidaturas dos partidos aqui estudadas. Nesta seção são apresentados os sentidos e os momentos na formação da cadeia discursiva da campanha eleitoral de Lula de 1994, tratando do Plano Real. Para isso, foram transcritos ao todo 24 programas eleitorais do PT veiculados durante o HGPE na eleição de 1994, o que representa a totalidade dos programas do partido - não repetidos. Desse total, de forma direta ou relacionados a outro tema, 12 abordaram o tema "Plano Real". Assim, verifica-se que o tema "Plano Real" foi tratado em metade (50\%) dos programas eleitorais petistas.

Da mesma forma que no discurso da candidatura do PSDB, apresentada na seção anterior, foi possível verificar três fluxos argumentativos que constituíram sentidos em relação ao Plano Real abordado pela candidatura do PT, e que explicitaram a relação antagônica entre as candidaturas aqui tratadas a partir da formação de seus momentos e do próprio discurso. São eles: "plano eleitoreiro"; "mudanças negativas e insuficientes" e "aprimoramento do Real". A relação entre esses momentos originou o discurso "Plano Real: crítica a um modelo incompleto".

\section{Momento 1: Plano eleitoreiro}

Um dos principais sentidos tratados pela candidatura petista girou em torno das "artimanhas" utilizadas pela candidatura tucana e das "mentiras" contadas pelo seu principal adversário em relação ao Plano Real. Vejamos:

Locutor: Utilização da máquina pública por parte do governo Itamar, favorecendo a campanha de Fernando Henrique. Abuso de poder é crime eleitoral! (...) Fernando Henrique mostra plano de governo falso em programa de TV. Fernando Henrique esconde seus aliados (Programa Eleitoral Lula/PT, HGPE, 26/8/1994).

A passagem a seguir, que trata da fala de Ricupero, apresenta, de forma resumida, os fatos que, segundo a candidatura do PT, comprovam a estratégia eleitoreira do candidato do PSDB.

Locutor: Atenção eleitor, você vai ter a rara chance de ver como os poderosos se organizam para fraudar a esperança do povo. Quinta-feira, o Ministro Rubens Ricupero, sem saber que suas declarações estavam sendo transmitidas pela TV, confessou o apoio da máquina do governo à candidatura de Fernando Henrique. Ricupero quis negar que a inflação de agosto tenha sido de 5,8\%, acusando os técnicos do IBGE de manipular o IPC-R, e 
confessou que está escondendo a inflação. Fala de Ricupero: No fundo é isso mesmo, eu não tenho escrúpulos, o que é bom a gente fatura, o que é ruim, a gente esconde. Locutor: Ricupero vangloriou-se de estar apoiando Fernando Henrique. Fala de Ricupero: Você sabe, eu não digo isso, mas há inúmeras pessoas que me escrevem, que me procuram, que vão votar nele por causa minha. Aliás, ele sabe disso, que o grande eleitor dele sou eu. Eu ouço muita gente que não votaria nele por causa do $\mathrm{PFL}$, e vai votar por causa minha. Locutor: Ricupero revelou o envolvimento da Rede Globo no apoio a Fernando Henrique. Fala de Ricupero: Para a Rede Globo foi um achado, porque, ao invés de dar apoio ostensivo a ele, botam a mim no ar, e ninguém pode dizer nada. Agora o PT tá começando, mas não pode, porque eu estou o tempo todo no ar e ninguém pode dizer nada, não é verdade? Locutor: Ricupero se escalou para aparecer no Fantástico. Fala de Ricupero: Se quiser, nesse fim de semana, podia ver o negócio do Fantástico, eu posso gravar também se quiser. Porque eu acho bom, porque nessa fase, meu caro, por causa do IPC$\mathrm{R}$, eu estou querendo. É por isso que eu resolvi ficar no ar o tempo todo. Locutor: A estabilidade da economia é o sonho de todos os brasileiros, a farsa revelada aumenta ainda mais a responsabilidade do voto nessas eleições. Você é quem vai decidir se quer um Brasil com base no único valor capaz de construir uma nação: a verdade (Programa Eleitoral lula/PT, HGPE, 31/8/1994).

Nesse trecho, novos elementos produzem sentido no que se refere ao Plano Real e à forma como a candidatura do peessedebista FHC foi construída em torno de uma mentira. Um dos principais sentidos em relação a esse momento discursivo da campanha eleitoral do petista Lula trata do fato de que o governo e o seu candidato estariam escondendo a inflação a partir da manipulação de informações sobre a economia, construindo inverdades que se sustentariam a partir da imagem do ministro da Fazenda Rubens Ricupero.

Esse episódio, sem dúvida, possibilitou a ampliação dos sentidos antagônicos ao plano defendido pela candidatura do peessedebista FHC. Valendo-se disso, Lula aproveita para tentar criar um diálogo direto com o eleitor, como podemos perceber:

Lula: Ficou claro para o povo brasileiro, nesse episódio do Ministro Ricupero, a falta de ética, a falta de respeito e a falta de credibilidade dos nossos dirigentes. Não basta simplesmente trocar de ministro. É preciso, sobretudo, trocar de postura e respeitar a nação. O que está em jogo nessas eleições são dois projetos. Um que quer controlar a inflação e estabilizar a economia apenas por 30 dias. E outro, que é o nosso, que quer estabilizar a economia e controlar a inflação de forma duradoura. E eu queria convidar vocês, para 
junto comigo, construir esse Brasil baseado, sobretudo, na verdade (Programa Eleitoral Lula/PT, HGPE, 13/9/1994).

Conforme a candidatura petista, a postura adotada pelo governo em defesa de seu candidato favorito demonstrava um desrespeito à nação, pois o Plano não visa a controlar a inflação e estabilizar a economia de forma duradoura, como o plano pretendido pelo possível governo do PT. Ainda tratando sobre o caráter eleitoreiro do Plano, o vice de Lula, Aloizio Mercadante (PT), afirma o seguinte:

Mercadante: As coisas graves que o Ministro Ricupero deixou escapar naquela entrevista é [sic] parte do plano de governo para importar tudo até as eleições, para garantir resultados políticos para seu candidato. Esse Plano é inaceitável, é irresponsável, eles vão queimar as reservas cambiais do país para trazer produtos lá de fora, impedindo as empresas brasileiras de vender sua produção, de produzirem, e, portanto, de gerar emprego e salário. Nós precisamos de uma política que combata a inflação sim, mas que combata a inflação investindo, gerando produção, permitindo aos brasileiros terem emprego e salário para comprar (Programa Eleitoral Lula/PT, HGPE, 7/9/1994).

Nesse instante podemos verificar a relação de equivalência entre elementos que indicam, a partir dos diversos sentidos gerados com base nos pronunciamentos contidos na candidatura petista, a existência de um plano eleitoreiro por parte da candidatura do PSDB - denominamos essa relação entre esses sentidos de "Plano eleitoreiro", o primeiro momento da estruturação do discurso antagônico da candidatura do PT.

\section{Momento 2: Mudanças negativas e insuficientes}

Contrariando, em grande medida, as afirmações dos programas eleitorais da candidatura tucana, a campanha eleitoral da candidatura petista buscou desconstruir o entendimento de ganhos que o Plano Real possibilitou à população brasileira, informando, de modo geral, a limitação do Plano. Os primeiros elementos que atribuíram sentidos ao entendimento de que o Plano Real na verdade propiciou mudanças negativas em seus primeiros instantes de implementação podem ser percebidos no trecho que segue:

Locutor: Dois projetos disputam esta eleição. Se o projeto deles ganhar, algumas empresas vão competir no mercado mundial. Mas a grande maioria não vai. Algumas regiões do país vão produzir para vender lá fora. Mas a maioria não vai. Algumas pessoas vão viver ainda melhor. Mas a maioria do povo vai continuar de fora. Disso vai resultar uma nação com mais desigualdades e injustiças. O nosso projeto é outro. Nós queremos integrar e fortalecer o Brasil. Desenvolver o mercado interno. Dar poder de compra aos 
salários. Apoiar a pequena e média empresa. O pequeno e médio produtor rural. Defender a indústria brasileira. Valorizar os que vivem do trabalho, pois o futuro está com eles. Dê uma chance ao Brasil, a esperança é Lula (Programa Eleitoral Lula/PT, HGPE, 21/8/1994).

Fazendo uma relação dos dois projetos que disputam a eleição de 1994, mesmo não havendo menção direta ao Real (pronunciando a palavra "real"), o locutor do programa eleitoral de Lula enfatizava suas diferenças caracterizando o projeto de governo da candidatura de FHC (que está ancorado no Plano Real) como limitado, que propiciava pouca competitividade no mercado mundial e permitiria a melhora da vida de poucas pessoas. No tocante à forma de governar e à implementação do Plano Real, novos elementos produzem sentido no que diz respeito às mudanças negativas com o Plano.

Mercadante: Temos que nos preocupar, $12 \%$ de inflação nos dois primeiros meses do Real é a maior inflação no início do Plano de todas as tentativas de combate à inflação dos últimos anos. O governo precisa assumir já as suas responsabilidades. Convocar os trabalhadores e os empresários, para juntos com o governo controlar a inflação dos principais setores da economia. Em segundo lugar, baixar as taxas de juros e ter coragem para desmontar esta ciranda financeira e proteger a caderneta de poupança. Em terceiro, o governo tem que romper com o palanque do outro candidato, não permitir que o objetivo eleitoreiro arrebente com o orçamento e promova o déficit público. Se esse governo tiver a estatura, a dignidade, ele rompe com o outro candidato, mas ele protege os interesses gerais da nação brasileira (Programa Eleitoral Lula/PT, HGPE, 28/8/1994).

O aumento da inflação nos primeiros meses do Plano Real já sinalizava mudanças negativas, significadas como medidas irresponsáveis do governo para proteger o candidato do PSDB (FHC). O trecho a seguir demonstra uma perspectiva de contrariedade em relação ao plano político implementado até aquele momento:

Lula: Eu quero ser Presidente da República porque acho que tenho condições de fazer pelo Brasil o que as elites dirigentes não fizeram nesses quase 500 anos. Eu tenho consciência que eu posso estabelecer uma outra relação entre Estado e povo, entre patrão e empregado, entre a sociedade civil organizada e o Estado brasileiro. Nós temos que estabelecer coisas concretas, que o povo acredite, que seja possível de dar certo, até porque nós temos um povo extraordinário que não está precisando de migalhas de governo, não está precisando de favor (Programa Eleitoral Lula/PT, HGPE, 24/8/1994).

As críticas feitas nos programas eleitorais da candidatura petista ao governo e seu candidato preferido apontam a manutenção das alianças com grupos que já ocupam o poder político no Brasil há certo tempo como um aspecto negativo. Outro aspecto negativo 
atribuído a FHC e significado no programa eleitoral de Lula diz respeito à política de importação implementada pelo seu adversário:

Locutor: Graças à decisão de Ciro Gomes e Fernando Henrique de reduzir as tarifas para importação, está havendo aumento de empregos no Japão, na Alemanha, nos Estados Unidos, na Itália e na França. Enquanto isso no Brasil as máquinas estão paradas e uma nova onda de desemprego se anuncia. Os trabalhadores precisam de um governo que fale a língua do povo (Programa Eleitoral Lula/PT, HGPE, 24/8/1994).

Tais elementos apontam para uma perspectiva crítica em relação às conquistas que, segundo os programas eleitorais da candidatura tucana, eram positivas. Deste modo, os sentidos identificados até aqui indicam que, na verdade, conforme os programas da candidatura petista, o Plano se caracterizou por desenvolver medidas negativas em relação à economia, o que refletiu na sociedade de modo geral. Assim, o segundo momento do discurso antagonicamente construído na candidatura do PT na campanha eleitoral de 1994 ficou simbolizado a partir da ideia de "mudanças negativas e insuficientes".

\section{Momento 3: Aprimoramento do Real e resposta à política do medo}

Uma das principais características evidenciadas nesse momento é a de que, se eleito, o governo do petista Lula buscaria manter e melhorar o Real. Além disso, outros sentidos se constituíam em resposta à "política do medo" (de não ser aliado do Real) que era desenvolvida na candidatura do PSDB.

Lula: Tenho em mente as eleições de 1989, e tenho em mente as mentiras que foram contadas naquelas eleições. Vocês estão lembrados que os mesmos que falavam que eu ia acabar com a poupança, acabaram com a poupança, ou melhor, roubaram a poupança do nosso povo. Aqueles mesmos que diziam que eu ia acabar com a poupança estão dizendo agora que nós vamos acabar com o Real. E nós não queremos acabar com o Real, o que nós queremos é colocar mais reais no bolso do trabalhador, porque não basta moeda forte, é preciso salário forte também. Vocês estão lembrados que diziam que nós não tínhamos experiência, e os experientes que estiveram no poder sempre no Brasil não conseguiram resolver os problemas da educação, da saúde, da agricultura, da reforma agrária e da ciência e tecnologia. Hoje nós temos a pior saúde do mundo e a pior educação do mundo. Esses mesmos que são responsáveis pelo fato do Brasil ter a maior taxa de desemprego da década (Programa Eleitoral Lula/PT, HGPE, 5/8/1994).

No excerto acima, Lula busca desconstruir um discurso que afirma que sua vitória representaria o fim do Real. Nesse sentido, o candidato petista afirma que, diferentemente 
do que seu concorrente vinha declarando, não iria acabar com o Real; Lula garante que iria manter o Real e, a partir de seu aperfeiçoamento, buscaria melhorar os salários para atacar os problemas do Brasil. Sobre a continuidade do Real, Aloizio Mercadante (PT), vice de Lula em 1994, afirma o seguinte:

Mercadante: Quando vimos, finalmente nós temos uma moeda, mas se a gente falar a verdade, e você sabe disso, este Plano não foi feito para estabilizar a economia para valer, pra ter uma moeda forte e duradoura. Esse Plano foi feito pra tentar impedir o Lula de ganhar as eleições. É por isso que nós queremos ser muito diretos com vocês. O poder econômico aceitou isso só 3 meses antes das eleições, para não ter risco e não perder dinheiro. E nós temos de ter uma atitude inteligente. Vamos pegar essa moeda forte sim, mas vamos tirar eles do poder e pôr o Lula para fazer as reformas profundas que o país precisa (Programa Eleitoral Lula/PT, HGPE, 24/8/1994).

Segundo Mercadante, a moeda era forte e boa, mas estava nas mãos erradas. Ainda, conforme o pronunciamento do vice de Lula em 1994, a moeda teria de ser duradoura, e não apenas para essa eleição - a moeda não podia ser apenas uma estratégia para impedir Lula de ganhar as eleições. Tal afirmação pode ser justificada pelo fato de que Lula liderava as intenções de votos antes do Real e, com o Plano, a popularidade de $\mathrm{FHC}$ acabou aumentando ${ }^{30}$. Em consequência, em resposta à política do medo e para criar um panorama de futuro - aperfeiçoamento do Real -, Mercadante afirma que o governo Lula, se eleito, manteria e aperfeiçoaria o Real.

Ao se referir à "política do medo", Lula diz:

Lula: O que nós queremos é uma economia forte, uma economia estabilizada com uma inflação controlada. Pra isso, no meu governo, a gente vai estabelecer acordos setoriais com empresários, com trabalhadores e com o governo. A partir daí a gente vai ter o controle de preços, a gente vai ter política salarial, a gente vai ter diminuição de juros e a gente vai ter diminuição dos impostos. Fazendo isso, pode estar certo, que o Brasil vai dar certo (Programa Eleitoral Lula/PT, HGPE, 7/9/1994).

Em uma resposta clara à "política do medo", Lula afirmava que, se eleito, buscaria "dialogar" com empresários e trabalhadores para construir acordos para fazer o "Brasil dar certo". Para isso, o candidato do PT não apresenta em momento algum a ideia de acabar com o Real, pelo contrário, tendo como base seus pronunciamentos anteriores, o excerto acima exemplifica sua resposta à política do medo e seu caminho para aperfeiçoar o Real. Nesse mesmo sentido: "Locutor: Lula, sindicalista, deputado, um brasileiro que venceu a batalha da vida. Lula não mudou de lado, não desistiu de um país mais justo, onde todos

30 Disponível em: <http://datafolha.folha.uol.com.br/eleicoes/1994/10/1203291-intencao-de-votopresidente---1994.shtml>. Acesso em: 1 ago. 2016. 
sejam cidadãos de verdade. Lula presidente, sem mentira, sem medo de ser feliz" (Programa Eleitoral Lula/PT, HGPE, 24/8/1994).

Conforme o excerto acima, representado pela fala do locutor da candidatura petista nas eleições de 1994, é possível verificar, novamente, uma resposta à "política do medo". Num entendimento de que Lula não mudou de lado e de que não desistiu de construir um país mais justo, aliado à afirmação "sem medo de ser feliz", apresentam sentidos que buscam contrapor as incertezas de seu possível governo em relação à economia. Em consequência, os elementos apresentados até este momento desta seção indicam sentidos que constituem um momento que trata da continuidade e do aperfeiçoamento do Real, bem como uma resposta à "política do medo" ventilada na candidatura tucana que tinha a intenção de colocar Lula e o PT como "inimigos" do Real.

Finalizada a composição do discurso da candidatura do PT nas eleições de 1994 a partir dos momentos já estruturalmente identificados e posicionados, na próxima subseção são apresentadas a sistematização do discurso da candidatura petista e sua configuração antagonicamente instituída, bem como a definição de seu ponto nodal.

\section{Plano Real: Crítica a um modelo incompleto}

A temática que pautou grande parte dos programas eleitorais da candidatura do PT na eleição de 1994 foi o Plano Real. Outros temas apareceram nos pronunciamentos contidos nos programas veiculados no HGPE da candidatura petista, mas não apresentaram sentidos antagônicos em relação à candidatura tucana. Foi possível verificar uma relação entre elementos dispersos que geravam sentidos diferentes em relação ao Plano Real. Constituída uma relação entre esses elementos, foi possível identificar que a candidatura petista se mostrava contrária à forma como o Plano estava sendo estruturado e utilizado pela candidatura tucana. A partir da relação entre esses elementos e dos sentidos gerados, foi identificada a construção de momentos que significavam o Plano Real e que estruturavam o discurso da candidatura do PT.

O primeiro momento identificado foi "plano eleitoreiro". O principal ponto deste momento discursivo era a desconstrução da informação, fornecida pela candidatura tucana, de que o Plano Real seria a salvação da economia brasileira a partir da necessidade de controlar a inflação e estabilizar a economia do país. Assim, a candidatura petista defendeu que o Plano, na verdade, não passava de um "Plano eleitoreiro", visto que o Plano não passava de paliativo e que não resolveria os problemas mais graves da economia brasileira, que eram a falta de produção e os altos juros cobrados. O segundo momento percebido foi "mudanças negativas e insuficientes". Nesse momento o principal ponto da crítica feita pela candidatura petista se referia às mudanças negativas que o Plano iria instituir, pois este beneficiaria apenas uma pequena parcela da sociedade. Esse momento se constitui em contraposição às afirmações feitas pela candidatura tucana, que enalteciam as conquistas imediatas com o Plano e as melhorias futuras que seriam possíveis a partir 
de sua continuidade. O terceiro momento detectado foi "aperfeiçoamento do Real e resposta à política do medo". Diferentemente dos momentos anteriores, em que o PT buscava atacar a candidatura peessedebista, esse momento se constitui em resposta às afirmações feitas pela candidatura adversária. Em resposta, os pronunciamentos contidos nos programas da candidatura do PT informavam que Lula não iria acabar com o Real nem agiria de forma irresponsável em relação à economia.

Assim sendo, foram apresentados os sentidos do discurso de campanha à Presidência da República de Lula nas eleições de 1994. Então, a articulação dos momentos em torno do discurso "Plano Real: críticas a um modelo incompleto" apresentou sentidos variados indicando a estratégia adotada pela campanha de FHC na utilização do Real como um "Plano eleitoreiro", contrariando os supostos benefícios do Plano quando apresentou "mudanças negativas e insuficientes" e respondendo às ofensivas sobre a atitude de Lula se fosse eleito presidente do Brasil em "aperfeiçoamento do Real e resposta à política do medo".

Figura 2

Discurso da candidatura do PT na eleição de 1994

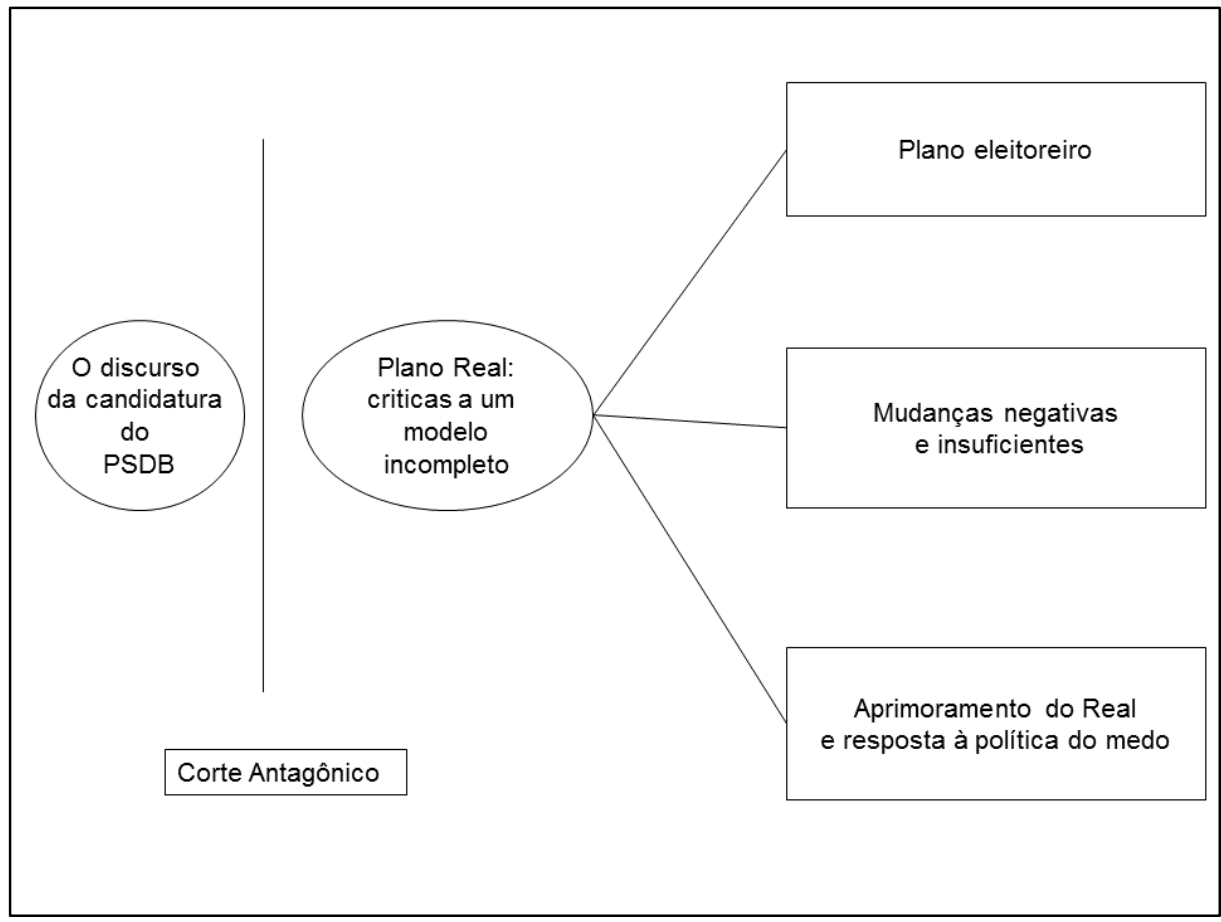

Fonte: Elaborado pelo autor a partir dos programas veiculados no HGPE (1994).

Realizada a apresentação da formação do discurso da candidatura de Lula na campanha à presidência da República na eleição de 1994, pôde-se perceber que os momentos discursivos apresentaram sentidos opostos aos do discurso produzido pela 
candidatura de FHC. Com isso, ficou evidenciada sua relação antagônica com o discurso produzido pela campanha de FHC. Assim, a campanha de Lula hegemonizou um discurso - interno a sua própria articulação - criticando a forma como o Plano Real estava sendo implementado pelo seu adversário (e pelo governo do qual fazia parte nesse contexto específico).

Amaral (1995) entende que Lula (e sua candidatura) não conseguiu produzir um discurso de oposição ao Plano Real e a FHC em virtude do sucesso do Plano e da estabilização da moeda com o controle da inflação. Para o autor, a estratégia da candidatura petista era confusa, pois num dia atacava o Plano e no outro o defendia. No entanto, a posição "mais clara" era a de ataque ao Plano, informando que o Real se constituía num plano burguês e seria mais um programa econômico fracassado. Por isso, a candidatura do PT não teve êxito na campanha eleitoral, não conseguindo construir uma nova opção ao Plano Real. O enfoque dado neste artigo aponta para uma direção alternativa. O antagonismo evidenciado apenas colocou o Plano Real como ponto nodal e o discurso da candidatura petista buscou construir sentidos que descolassem o Plano de seus idealizadores, questionando não o sucesso e a necessidade do Plano, mas os objetivos de seus "criadores". Isso pode ser mostrado pelo fato de a candidatura petista afirmar que o Plano estava sendo usado de forma "eleitoreira", e, ao mesmo tempo, apresentar proposta de melhorias em relação ao Plano, como evidenciado, em parte, pelo próprio Roberto Amaral. Portanto, as críticas eram contra a forma com os idealizadores e executores do Plano estavam tratando o Plano Real, e não contra o Plano, pois, como mostramos, no discurso petista existia a "crença" no "aperfeiçoamento do Real".

\section{Conclusões: a eleição de 1994 e o primeiro grande antagonismo entre PSDB e PT}

Até o ano de 1992, a aproximação ideológica (se é que se pode classificar dessa forma ${ }^{31}$ ) entre PT e PSDB, mesmo que houvesse diferenças em seus programas formadores, ainda pôde ser percebida. Isso mudaria substancialmente nos anos seguintes, principalmente a partir da disputa eleitoral de 1994. É importante atentar para a questão de que os dois partidos se aproximaram graças ao fato de que articulavam significações semelhantes em relação à conjuntura política do período da transição democrática e da elaboração da Constituição de 1988. Entre outros aspectos, não concordavam com o modo como a transição foi realizada e como os partidos governistas se portaram nos primeiros anos da redemocratização. Outro ponto relevante foi o de que os políticos que fundaram o PSDB, na sua grande maioria, quando ainda eram integrantes do PMDB, não "aprovaram"

\footnotetext{
31 Ideologia é aqui entendida como todo ato de decisão e, portanto, constituído por elementos políticos. Nesse sentido, e para uma maior compressão, ver Laclau (2000, 2011, 2013, 2015). Existem outras interpretações sobre ideologia (e não necessariamente antagônicas), para isso ver um apanhado dessas interpretações no livro organizado por Zizek (1996).
} 
parte relevante dos elementos defendidos e votados durante a Assembleia Nacional Constituinte (ANC) $)^{32}$.

Com o impeachment de Fernando Collor de Mello, em 1992, tanto Lula e o PT como FHC e o PSDB foram convidados a compor um "novo governo" comandado pelo então vice de Collor, Itamar Franco. Nesse contexto e com vistas à campanha eleitoral de 1994, Lula preferiu não fazer parte do governo que se formava (rearticulava), até porque algumas pesquisas apontavam seu favoritismo para a eleição seguinte (Amaral, 2003, p. 106) ${ }^{33}$. Diferentemente de Lula, FHC aceitou o convite e assumiu o Ministério de Relações Internacionais, fato que daria início a uma nova estruturação da campanha eleitoral que viria. Menos de um ano depois, em 1993, FHC foi convidado para ser o Ministro da Fazenda, espaço que Ihe conferiu maior projeção política. A partir daí, FHC deu início ao projeto de "reformular" a economia brasileira com o Plano Real, o qual obteve o êxito esperado, marcando, de forma definitiva, o espaço conquistado por FHC e abrindo caminho para a sua candidatura à presidência da República na eleição de 1994 (Mendes e Venturi, 1994).

Se levarmos em consideração o momento político da formação do PSDB, é possível identificar uma "articulação ideológica" com o que era defendido pelo PT. Foi no ano de 1993 que essa "articulação ideológica" começou a perder força, quando o PSDB e FHC aceitaram o convite de Itamar Franco para participar do governo peemedebista. Logo, os anos de 1993 e 1994, durante o governo de Itamar Franco, foram marcados por articulações políticas que definiria o futuro Presidente da República. Lula e FHC, antes aliados políticos, como no segundo turno das eleições presidenciais de 1989, se tornaram adversários em 1994. PT e PSDB tomaram rumos diferentes, que os colocaram como inimigos em relação à disputa à presidência da República nas eleições de 1994; fato que se manteve em todos os níveis da política até os dias de hoje. De certa forma, essa separação e a posição adotada pelo PT acabaram jogando o PSDB para a centro-direita do espectro político nacional, o que se evidencia, em grande medida, pela aliança feita com o PFL e pelas políticas adotadas durante o governo de FHC (Roma, 2002). Assim, a eleição de 1994 começava a colocar PT e PSDB como os principais inimigos no cenário político nacional.

Após essa construção contextual da relação entre PSDB e PT, identificamos que a eleição à presidência da República de 1994 foi o primeiro momento de disputa antagônica entre os partidos. Como demonstrado, o Plano Real assumiu o ponto nodal no que diz respeito às disputas por sentidos. A relação antagônica entre PSDB e PT se deu a partir da formação de dois polos discursivos e antagônicos em torno daquele Plano.

Sendo assim, a candidatura do PSDB, representada pelo candidato FHC, hegemonizou um discurso - interno à sua própria articulação - que colocou o Plano Real

\footnotetext{
32 Analisando os aspectos da ANC, pode-se identificar a aproximação ideológica entre os integrantes do PT e os futuros fundadores do PSDB como possível e, por esse motivo em especial, o PSDB ser visto, em sua posição original, como de esquerda (Kinzo, 1989).

33 Disponível em: <http://datafolha.folha.uol.com.br/eleicoes/1994/10/1203291-intencao-de-votopresidente---1994.shtml>. Acesso em: 1 ago. 2016.
} 
como o elemento fundamental para que se conseguisse a estabilidade econômica. Nesse tocante, a articulação dos momentos em torno do discurso "Plano Real: a conquista da estabilidade econômica" apresentou sentidos variados que sustentaram o "combate à inflação" (momento 1), as "mudanças positivas com o Real" (momento 2) e a necessidade de "manutenção do Real" (momento 3) com FHC no governo.

Em oposição, e em grande medida em resposta às afirmações feitas nos programas do PSDB veiculados no HGPE em 1994, o Plano Real também foi o ponto nodal do discurso da candidatura petista; por isso a relação entre as candidaturas colocou o Plano no centro do debate antagonicamente estruturado. A partir disso, diversos sentidos foram ventilados durante os programas da candidatura petista, o que possibilitou a identificação de momentos distintos que constituíram seu discurso. Os argumentos em torno do Plano Real nos pronunciamentos da candidatura petista nas eleições de 1994, organizados a partir dos momentos "Plano eleitoreiro" (momento 1), "mudanças negativas e insuficientes" (momento 2) e "aprimoramento do Real e resposta à política do medo" (momento 3), constituíram o ponto nodal "Plano Real: críticas a um modelo incompleto" (o discurso da candidatura petista).

Nesse contexto, o campo da discursividade foi composto pela luta política imersa nos programas eleitorais veiculados durante o HGPE, que, como buscamos apresentar, por se tratar de um espaço de luta (conflito), é, em alguma medida, constituído por elementos antagônicos. Aqui ficou evidenciada a disputa pelos sentidos em torno do Plano Real, ou seja, a relação antagônica entre as candidaturas se deu em relação ao Plano. A partir disso, e entre outros aspectos referentes ao HGPE como sendo um canal importante que auxilia na tomada de decisão por parte do eleitor, como a própria propaganda negativa, podemos inferir que a dimensão do antagonismo identificada nesse espaço de conflito permite aos eleitores um maior acesso informativo sobre as candidaturas a partir de seu caráter desconstrutivista. A disputa política eleitoral neste contexto foi marcada pela disputa pelos sentidos em torno do Plano Real e seu reflexo para a sociedade brasileira como um todo, o que caracteriza uma luta por hegemonia. Ambos os discursos disputaram os sentidos do Plano na tentativa de convencer o eleitor do que era "verdade" e/ou "mentira" não só em relação ao Plano, mas também em relação aos partidos e candidatos em disputa.

A centralidade do Plano Real na eleição de 1994 - como já verificada por Mendes e Venturi (1994), Amaral (1995), Jorge (1995), Almeida (1996, 1998), Miguel (1997), Porto e Guazina (1999), Mendes (2004), Oliveira (2005) e Souza (2012) - foi confirmada a partir de uma releitura da teoria do discurso de Laclau e Mouffe e principalmente a partir do conceito de antagonismo desenvolvido pelos autores. A novidade aqui não é a de apontar os argumentos das candidaturas de FHC e Lula em relação ao Plano Real nem mesmo indicar sua relevância para a eleição de 1994, mas demonstrar que esses argumentos se constituíram em sentidos de momentos dos discursos peessedebista e petista caracterizados por disputas políticas antagônicas, e que são refletidas até os dias de hoje, apresentando continuidades e descontinuidades; além de salientar a dimensão do 
antagonismo, que se verificou uma vez mais na eleição de 2018. Ampliando as evidências de Mendes e Venturi (1994), entendemos que a própria posição antagônica da candidatura do PT e de Lula em relação à candidatura do PSDB e FHC foi elemento sobressaliente para que o eleitorado identificasse o Plano como construção de FHC. Ou seja, além de não conseguir barrar o Plano Real no Congresso, a desconstrução realizada pelo PT durante o HGPE não surtiu efeito, pelo contrário, ajudou a "nomear" o criador do Real. Também acrescentando aos dados de Porto e Guazina (1999), mesmo que por uma metodologia diferente ${ }^{34}$, verificamos que os sentidos sobre o Plano Real permearam grande parte dos pronunciamentos das candidaturas aqui estudadas e, por isso, serviram de elementos antagônicos em se tratando de "políticas futuras", "análise de conjuntura" e "propaganda negativa".

Portanto, a teoria do discurso possibilitou a compreensão das formações discursiva e de sua estruturação antagônica a partir de relações institucionalizadas e regradas; a formação dos sentidos nessa relação se deu por elementos antagônicos que foram originados por elementos discursivos que, carregados de sentidos, constituíram os momentos. As práticas discursivas criadas nas relações antagônicas foram produzidas por identidades concorrentes, o que também deu origem a processos de identificações a partir de determinadas disputas por determinados sentidos.

Esse retorno ao passado se deu por entendermos que os principais estudos sobre o HGPE não levaram em consideração o papel do antagonismo e do conflito político na formação e formatação dos programas eleitorais de ambas as candidaturas, e consideramos ser essa dimensão mais uma faceta que revela a importância do HGPE no processo de tomada de decisão por parte do eleitor, pois possibilita uma construção interpretativa a partir dos próprios programas eleitorais. Essa interpretação se dá para além da construção da imagem negativa de uma candidatura em relação à outra. Dá-se pelo fato de que a construção de sentidos antagônicos possibilita a desconstrução de uma candidatura pela outra, o que auxilia na tomada de decisão por parte do eleitor. Ainda nesse contexto específico, para reiterar as informações encontradas, identificamos nessa eleição de 1994 o primeiro momento antagônico entre os partidos PSDB e PT em nível nacional, seja em campanhas eleitorais ou na própria administração política do Estado brasileiro. Olhando o cenário político-eleitoral das eleições de 2018, mesmo não constituindo objeto deste artigo, podemos verificar ainda de forma intuitiva e sem grande aprofundamento teórico e empírico, que novos antagonismos emergiram entre as candidaturas de PT e PSDB, bem como em relação à candidatura de Jair Bolsonaro do PSL. Com isso, podemos perceber continuidades e descontinuidades nessas relações antagônicas; o plano econômico, ao que tudo indica, continua sendo um dos principais pontos de disputa e de antagonismo entre as candidaturas de PT e PSDB.

\footnotetext{
34 Os autores partem da metodologia desenvolvida por Joslyn (1990). Ver Porto e Guazina (1999, p. 8-9).
} 
Em se tratando dos aspectos referentes ao HGPE, por mais que críticas sejam feitas a determinados espaços como dominados por determinados modus operandi, como Miguel desenvolve em alguns de seus textos (Miguel, 1999, 2002, 2003, 2004a), entendemos que - HGPE se constitui como um espaço de disputa política. Mesmo tendo a grande mídia capacidade de interferir numa eleição (Lattman-Weltman, Carneiro e Ramos, 1994), a relação antagônica identificada entre as candidaturas do PSDB e do PT na eleição aqui estudada aponta para o fato de que o HGPE pode ser um espaço de luta política com capacidade de alterar perspectivas. Nesse sentido, os trabalhos de Machado (2009), Cervi, Massuchin e Tavares (2012), bem como alguns pontos identificados por Lourenço (2009), Dias (2013) e Borba (2015), indicam o aspecto de desconstrução atribuído ao HGPE neste artigo, podendo assumir uma capacidade de se contrapor à força de interferência da grande mídia e a sua "preferência" por algum candidato, como nas eleições de Lula em 2002 e 2006 e Dilma em 2010 e 2014.

Ampliando o que foi inferido no parágrafo acima, o HGPE possibilita um debate de desconstrução de candidaturas a partir da relação antagônica que ali poderá ser instituída. No caso estudado neste artigo, foi identificado o ponto antagônico entre as candidaturas do PSDB e do PT na eleição de 1994 a respeito da disputa à presidência da República. Ficou demonstrado que o HGPE se mostrou um espaço de disputa política, e por isso de conflito, em que as candidaturas concorrentes estudadas buscaram desconstruir as propostas uma da outra a partir de identificações políticas antagônicas. Estudos eleitorais sobre candidatos, partidos ou candidaturas constituem dimensões diferentes de um mesmo fenômeno. Por isso, nossa contribuição é apenas um elemento dessa relação: o antagonismo entre as candidaturas do PSDB e PT nas eleições de 1994.

A partir do exposto aqui, entendemos que a relação entre candidaturas é outro elemento que afeta, sobremaneira, a organização e a direção dada aos programas eleitorais veiculados no HGPE. Ademais, podemos afirmar, respaldados pela construção das candidaturas estudadas e a partir dos trabalhos citados no desenvolvimento deste artigo, que a influência do HGPE na decisão do eleitor, mesmo havendo constrangimentos e a construção direcionada de informações pelos principais veículos de informação da grande mídia, é relevante para estudos sobre propaganda eleitoral e comportamento político (Figueiredo e Aldé, 2003). À vista disso, o HGPE se mostra como um elemento importante no que diz respeito à própria disputa política travada entre candidatos e partidos (entre as candidaturas). 


\section{Referências bibliográficas}

Albuquerque, A. O espetáculo da crise: os meios e o processo de impeachment contra Collor. In: Pereira, C. A. M.; Fausto Neto, A. (orgs.). Comunicação e cultura contemporânea. Rio de Janeiro: Notrya, p. 144-148, 1993.

"Política versus televisão: o horário gratuito na campanha presidencial de 1994". Comunicação e Política, vol. 1, no 3, p. 24-54, 1995.

. "A batalha pela presidência: o Horário Gratuito de Propaganda Eleitoral na campanha de 1989". Tese de Doutorado em Ciência Política. Escola de Comunicação UFRJ, Rio de Janeiro, 1996.

Albuquerque, A.; DiAS, M. R. "Propaganda política e a construção da imagem partidária no Brasil". Revista Civitas, vol. 2, no 2, p. 308-326, 2002.

ALMEIDA, J. Como vota o brasileiro: perfil ideológico do eleitor e evolução nas pesquisas de opinião de 1994. São Paulo: Casa Amarela, 1996.

. A conquista do lugar de fala e a fala fora do lugar nos discursos de FHC e Lula sobre o Real. In: RUBIM, A.; BENTZ, I.; PINTO, M. (orgs.). Produção e recepção dos sentidos midiáticos. Petropólis: Vozes, p. 69-91, 1998.

. "Apelos eleitorais dos candidatos presidenciais do Brasil em 2006". Revista de Ciências Sociais, vol. 39, no 2, p. 44-60, 2008.

AMARAL, O. E. A estrela não é mais vermelha: as mudanças no programa petista nos anos 90 . São Paulo: Garçoni, 2003.

AmARAL, R. "Em busca do significado das eleições de 1994 (reflexões sujeitas a chuvas e trovoadas)". Comunicação \& Política, vol. 1, no 3, p. 5-48, 1995.

ARUGUete, N. "Los medios de comunicación y la formación de la agenda pública". Verso e Reverso, vol. 19, no 41, p. 73-98, 2005.

Biroli, F.; Miguel, L. "Meios de comunicação, voto e conflito político no Brasil". Revista Brasileira de Ciências Sociais, vol. 28, no 81, p. 77-95, 2013.

BORBA, F. "Propaganda negativa nas eleições presidenciais brasileiras". Opinião Pública, vol. 21, n० 2, p. 268-295, 2015.

BORBA, F.; VEIGA, L.; MARTINS, F. "Propaganda negativa na eleição presidencial de 2014: ou como tudo que é frágil se desmancha no ar". Revista Estudos Políticos, vol. 6, no 1, p. 171-189, 2015.

Brasil. Casa Civil da Presidência da República. Lei no 8.713, de 30 de setembro de 1993. Disponível em: <http://www.planalto.gov.br/ccivil_03/leis/L8713.htm>. Acesso em: 15 out. 2018.

. Câmara dos Deputados Federais. "Exposição de Motivos da MP do Plano Real". 1994. Disponível em: <http://www2.camara.leg.br/legin/fed/medpro/1994/medidaprovisoria-542-30junho-1994-375071-norma-pe.html>. Acesso em: 2 out. 2018.

Bresser-Pereira, L. C. "A economia e a política do Plano Real". Revista de Economia Política, vol. 14, n० 4, p. 129-149, 1994.

167-192, 2010.

"A descoberta da inflação inercial". Revista de Economia Contemporânea, vol. 14, no 1, p.

Cervi, E. U.; Massuchin, M. G.; Tavares, C. Q. "Agenda da mídia, dos políticos e do público na campanha eleitoral de 2010". Revista Debates, vol. 6, no 1, p. 237-261, 2012.

Colletti, L. "Marxism and the dialectic". New Left Review, no 93, p. 3-29, 1975.

DIAS, M. R. "Nas brumas do HGPE: a imagem partidária nas campanhas presidenciais brasileiras (1989 a 2010)". Opinião Pública, vol. 19, no 1, p. 198-219, 2013. 
ESTATUTO do PSDB. Partido da Social Democracia Brasileira [on-line], 2011. Disponível em: <www.psdb.org.br>. Acesso em: 23 jan. 2015.

MANIFESTO DE FUNDAÇÃo do PT. Fundação do Partido dos Trabalhadores, [on-line] 1980. Disponível em:<http://www.pt.org.br/manifesto-de-fundacao-do-partido-dos-trabalhadores/>. Acesso em: 06 dez. 2018.

FAusto Neto, A. "O presidente na televisão. A construção do sujeito e do discurso político no guia eleitoral". Comunicação \& Política, vol. 2, no 11, pp. 7-27, 1990.

As vozes do impeachment. In: Matos, H. (org.). Mídia, eleições e democracia. São Paulo: Scritta, p. 191-205, 1994.

O impeachment da televisão. Rio de Janeiro: Diadorim, 1995.

Figueiredo, M. "Intenção de voto e propaganda política: efeitos da propaganda eleitoral". Logos, vol. 27, no 2, p. 9-20, 2007.

Figueiredo, M.; ALDÉ, A. "Intenção de voto e propaganda política: efeitos e gramática da propaganda eleitoral (notas para um debate)". Anais do $12^{\circ}$ Encontro da Anual da Compós, Recife, 2003.

Figueiredo, M., et al. Estratégias de persuasão em eleições majoritárias: uma proposta metodológica para o estudo da propaganda eleitoral". In: FigueIREDo, R. (org.). Marketing político e persuasão eleitoral. São Paulo: Konrad Adenauer, p. 147-203, 2000.

FLEISCHER, D. Manipulações casuísticas do sistema eleitoral durante o período militar, ou como usualmente o feitiço voltava contra o feiticeiro. In: SOARES, G.; D'ARAUjo, M. C. (orgs.). 21 anos de regime militar: balanços e perspectivas. Rio de Janeiro: Fundação Getúlio Vargas, p. 154-197, 1994.

FOLHA DE S. PAULO. "Bolsonaro representa risco à democracia, escreve The Economist". Disponível em: <https://www1.folha.uol.com.br/mercado/2018/08/bolsonaro-representa-risco-a-democraciaescreve-the-economist.shtml>. Acesso em: 4 ago. 2018.

GARCIA, C. PT: de oposição à sustentação da ordem. 2a ed. Rio de Janeiro: Achiamé, 2012.

Guiot, A. P. "Um 'moderno Príncipe' para a burguesia brasileira: o PSDB (1988-2002)". Dissertação de Mestrado em História, Departamento de História UFF, Rio de Janeiro, 2006.

IANONI, M. "Políticas públicas e Estado: o Plano Real". Lua Nova, vol. 78, p. 143-183, 2009.

JoRGE, V. L. "Eleição presidencial de 1994 e os meios de comunicação de massa: uma análise da Propaganda Eleitoral Gratuita de Fernando Henrique Cardoso e Luiz Inácio Lula da Silva na televisão". Dissertação de Mestrado em Ciência Política, Programa de Pós-Graduação em Ciências Sociais Iuperj, Rio de Janeiro, 1995.

JoSLYN, R. Election campaigns as occasions for civic culture. In: SWANSON, D.; Nimmo, D. (orgs.). New directions in political communication. Newbury Park: Sage, p. 86-119, 1990.

KInzo, M. D. G. "O quadro partidário e a Constituinte". Revista Brasileira de Ciência Política, Brasília, vol. 1, no 1, p. 91-124. 1989.

LACLAU, E. Nuevas reflexiones sobre la revolución de nuestro tiempo. 2a ed. Buenos Aires: Nueva Visión, 2000 [1990].

Emancipação e diferença. Rio de Janeiro: Eduerj, 2011 [1996].

. A razão populista. São Paulo: Três Estrelas, 2013 [2005].

. Los fundamentos retóricos de la sociedad. Buenos Aires: Fundo de Cultura Económica, 2014.

LACLAU, E.; MoufFE, C. Hegemonia e estratégia socialista: por uma política democrática radical. São Paulo: Intermeios; Brasília: CNPq, 2015 [1985].

Lattman-Weltman, F.; CARneiro, J.; Ramos, P. A imprensa faz e desfaz um presidente: o papel da imprensa na ascensão e queda de Fernando Collor. Rio de Janeiro: Nova Fronteira, 1994. 
LIMA JR., O. B. O sistema partidário brasileiro: diversidades e tendências (1982-1994). Rio de Janeiro: Fundação Getúlio Vargas, 1997.

LIMA, V. A. "Televisão e política: hipótese sobre a eleição presidencial de 1989". Comunicação \& Política, vol. 11, no 11, p. 29-54, 1990.

LOURENÇO, L. C. "Propaganda negativa: ataque versus votos nas eleições presidenciais de 2002". Opinião Pública, vol. 15, n 1, p. 133-158, 2009.

MACHADO, M. "A retórica da reeleição: mapeando os discursos dos programas eleitorais (HGPE) em 1998 e 2006". Opinião Pública, vol. 15, no 1, p. 159-189, 2009.

MAINWARING, S. P. Sistemas partidários em novas democracias: o caso do Brasil. Rio de Janeiro: Mercado Aberto, 2001.

Mainwaring, S. P.; Meneguello, R.; Power, T. Partidos conservadores no Brasil contemporâneo: quais são, o que defendem, quais são suas bases. São Paulo: Paz e Terra, 2000.

MANIFESTO DE FUndação Do PT. Fundação do Partido dos Trabalhadores, [on-line], 1980. Disponível em:<http://www.pt.org.br/manifesto-de-fundacao-do-partido-dos-trabalhadores/>. Acesso em: 6 dez. 2018.

MARQUeS, J. R.; FleisCheR, D. De facção a partido: PSDB. Brasília: Instituto Teotônio Vilela/Editora Positiva, 1999.

MASSUCHIN, M. G., et al. "A construção da campanha eleitoral majoritária no HGPE: uma análise comparada das estratégias usadas pelos presidenciáveis de 2014". Política \& Sociedade, vol. 15, no 32, p. 171-203, 2016.

MenDES, G. "Da Frente Brasil Popular à aliança capital e trabalho: as campanhas de Lula a presidente de 1989 a 2002". Dissertação de mestrado em Ciência Política, Programa de Pós-Graduação em Ciências Sociais Iuperj, Rio de Janeiro, 2004.

Mendes, A. M. T.; VentuRi, G. "Eleição presidencial: o Plano Real na sucessão de Itamar Franco". Opinião Pública, vol. 2, no 2, p. 59-72, 1994.

MENDONÇA, D. "A noção de antagonismo na ciência política contemporânea: uma análise a partir da perspectiva da teoria do discurso". Revista Sociologia e Política, vol. 20, no 1, p. 135-145, 2003a.

. "A teoria do discurso de Laclau e Mouffe: em direção à noção de significante vazio". Revista Barbarói, vol. 18, no 1, p. 55-71, $2003 \mathrm{~b}$.

. "A teoria da hegemonia de Ernesto Laclau e a análise política brasileira". Red de Revistas Cientificas da América Latina y el Caribe, vol. 43, no 3, p. 249-258, 2007.

. "Teorizando o agonismo: crítica a um modelo incompleto". Revista Sociedade e Estado, vol. 25, no 3, p. 479-497, 2010.

. "Antagonismo como identificação política". Revista Brasileira de Ciência Política, vol. 9, no 3, p. 205-228, 2012.

Meneguello, R. PT: a formação de um partido (1979-1982). São Paulo: Paz e Terra, 1989.

Miguel, L. F. "Mídia e discurso político nas eleições presidenciais de 1994". Comunicação \& Política, vol. 4, no 1, p. 80-96, 1997.

. "Mídia e manipulação política no Brasil: a Rede Globo e as eleições presidenciais de 1989 a 1998". Comunicação \& Política, vol. 6, no 2-3, p. 119-38, 1999.

. Mito e discurso político: uma análise a partir da campanha eleitoral brasileira de 1994. Campinas: Editora da Unicamp/Imprensa Oficial, 2000.

2002.

"Os meios de comunicação e a prática política". Lua Nova, vol. 2, no 55-56, p. 155-184, 
"Eleições, opinião pública e mídia: reflexões a partir das eleições brasileiras de 2002". Política \& Sociedade, vol. 2, n 2, p. 41-66, 2003.

"Discursos cruzados: telenoticiário, HGPE e a construção da agenda eleitoral". Sociologias, vol. 6, no 11 , p. 238-258, 2004a.

"Mídia e vínculo eleitoral: a literatura internacional e o caso brasileiro". Opinião Pública, vol. 10 , no 1, p. 91-111, 2004b.

MotTA, R. P. S. A reforma partidária de 1979-1980 e o quadro atual. Introdução à história dos partidos políticos brasileiros. Belo Horizonte: Editora UFMG, 2008.

NovaES, C. A. M. "Dinâmica institucional de representação". Novos Estudos Cebrap, no 38, p. 99-147, 1994.

OliveirA, L. A. "A disputa política na televisão: uma análise das estratégias discursivas dos candidatos Fernando Henrique Cardoso e Luiz Inácio Lula da Silva no Horário Gratuito de Propaganda Eleitoral". Dissertação de Mestrado em Ciência Política, Programa de Pós-Graduação em Ciências Sociais Iuperj, Rio de Janeiro, 2005.

Pinto, C. R. J. "Elementos para uma análise de discurso político". Revista Barbarói, vol. 1, no 24, p. 78-109, 2006.

Porto, M.; GuAZINA, L. "A política na TV: o horário eleitoral da eleição presidencial de 1994". Revista Contracampo, vol. 3, n 3, p. 5-33, 1999.

PROGRAMA do PSDB. Introdução e diretrizes básicas do Partido da Social Democracia Brasileira [online], 1988. Disponível em: <http://www.psdb.org.br>. Acesso em: 2 dez. 2014.

Programa do PT. Programa de governo 1989 [on-line], 1989. Disponível em: <www.pt.org.br>. Acesso em: 5 jan. 2015. 5 jan. 2015

Programa de governo 1994 [on-line], 1994. Disponível em: <www.pt.org.br>. Acesso em: 5 jan. 2015.

Programa de governo 1998 [on-line], 1998. Disponível em: <www.pt.org.br>. Acesso em:

REIS, F. W. "Identidade política, desigualdade e partidos brasileiros". Novos Estudos Cebrap, vol. 87, no 2, p. 61-75, 2010.

Rennó, L.; CABello, A. "As bases do lulismo: a volta do personalismo, realinhamento ideológico ou não alinhamento?". Revista Brasileira de Ciências Sociais, vol. 25, no 74, p. 39-60, 2010.

RodRIgUeS, L. M. Quem é quem na Constituinte: uma análise sociopolítica dos partidos e deputados. São Paulo: Oesp-Maltese, 1987.

"Partidos, ideologia e composição social". Revista Brasileira de Ciências Sociais, vol. 17, no 48, p. 31-47, 2002.

RomA, C. "A institucionalização do PSDB entre 1988 e 1999". Revista Brasileira de Ciências Sociais, vol. 17, n० 49, p. 71-92, 2002.

Rubim, A. A. C. "Comunicação, espaço público e eleições presidenciais". Comunicação \& Política, vol. 9, n० 2, p. 2-21, 1989.

Política em tempos de mídia: impressões de crises. In: Pereira, C.; Fausto Neto, A. (orgs.). Comunicação e cultura contemporânea. Rio de Janeiro: Notrya, p. 149-168, 1993.

Visibilidade e estratégias nas eleições presidenciais de 2002: política, mídia e cultura. In: RuBIM, A. A. C. (org.). Eleições presidenciais em 2002 no Brasil. São Paulo: Ed. Cult e Hacker Editores, p. 54-71, 2004.

Rubim, A. A. C.; Azevedo, F. A. "Mídia e política no Brasil: textos e agenda de pesquisa". Lua Nova, vol. 1, no 43, p. 189-216, 1998. 
O PRIMEIRO GRANDE ANTAGONISMO ENTRE PSDB E PT

Samuels, D. "As bases do petismo". Opinião Pública, vol. 10, no 2, p. 221-241, 2004.

"A evolução do petismo (2002-2008)". Opinião Pública, vol. 14, no 2, p. 302-318, 2008.

SILVA, P. S. "As estratégias dos candidatos na propaganda eleitoral presidencial de 1998". Revista Diálogos Possíveis, vol. 3, no 1, p. 61-77, 2004.

Singer, A. "Raízes sociais e ideologia do lulismo". Novos Estudos Cebrap, vol. 85, no 2, p, 83-103, 2009. 83-102, 2010.

"A segunda alma do Partido dos Trabalhadores". Novos Estudos Cebrap, vol. 88, no 2, p. Letras, 2012.

Os sentidos do lulismo: reforma gradual e pacto conservador. São Paulo: Companhia das

SOARES, G. S. "Os partidos políticos de esquerda e a consolidação da democracia brasileira". Interfaces, vol. 6, n० 2, p. 1-30, 2006.

SouzA, F. S. "Plano Real: a construção de um sentido hegemônico". Dissertação de Mestrado em Ciências Sociais. Programa de Pós-Graduação em Ciências Sociais UFPEL, Pelotas, 2012.

Terron, S. L.; SoARes, G. A. D. "As bases eleitorais do PT: do distanciamento ao divórcio". Opinião Pública, vol. 16, no 2, p. 310-337, 2010.

VIEIRA JÚNIOR, R. Ambientalistas e desenvolvimentistas: aplicando a teoria do discurso. Pelotas: Gráfica Universitária/UFPEL, 2010.

VoGEL, L. H. Negociar direitos? Legislação trabalhista e reforma neoliberal no governo FHC (19952002). Rio de Janeiro: Eduerj, 2013.

ZIZEK, S. (org.). Um mapa da ideologia. Rio de Janeiro: Contraponto, 1996 [1994].

Weber, M. H. A cara pintada da política. In: Pereira, C. A. M; Fausto Neto, A. (orgs.). Comunicação e cultura contemporânea. Rio de Janeiro: Notrya, p. 47-94, 1993.

\begin{abstract}
The first major antagonism between PSDB and PT

The objective of this article is to demonstrate the antagonistic construction between the discourses produced by the PSDB and PT candidacies during the HGPE television broadcast of the 1994 presidential election, which resulted in the Real Plan being posited as the nodal point of this conflict. We realize that the dimension of antagonism identified in this conflict zone allows voters greater access to information on the candidatures in dispute over the Presidency of the Republic, given its deconstructive character. Therefore, there are two main reasons that justify this study's focus on the past: a) this moment can be read as the first great antagonism between the PSDB and PT parties, and b) little or no attention has been paid to studies involving the antagonistic dimension of the HGPE, which may illuminate yet another aspect of the voter's vote choice. This work uses the theoretical and methodological aspects of Laclau and Mouffe's discourse theory to emphasize the concepts of discourse and antagonism essential to capturing the discursive meanings demonstrated here. We conclude, therefore, that the 1994 election marked the first major antagonism between PSDB and PT.
\end{abstract}

Keywords: HGPE; antagonism; discourse theory; PSDB; PT

\title{
Resumen
}

El primer gran antagonismo entre PSDB y PT

El objetivo de este artículo consiste en demostrar la construcción antagónica entre los discursos producidos por las candidaturas de PSDB y PT realizadas durante el Horario Gratuito de Propaganda Electoral (HGPE) promovidos por la televisión en la elección presidencial de 1994, que acabó colocando 
el Plan Real como el punto nodal de ese conflicto. A partir de eso, percibimos que la dimensión del antagonismo identificada en ese espacio de conflicto permite a los electores un mayor acceso informativo sobre las candidaturas en disputa por la Presidencia de la República, visto su carácter deconstructivista. Por eso, el retorno al pasado para ese estudio se justifica por dos principales razones: a) ese momento puede ser leído como siendo el primer gran antagonismo entre los partidos PSDB y PT; y b) que poca o ninguna atención ha sido dada por los estudios que involucran al HGPE a la dimensión antagónica, lo que puede iluminar otro de los aspectos referentes a la decisión del voto por parte del elector. Para ello, se utilizarán los aspectos teóricos y metodológicos de la teoría del discurso de Laclau y Mouffe, enfatizando los conceptos de discurso y antagonismo, imprescindibles para la captura de los sentidos discursivos que aquí se demuestren. Concluimos, por tanto, que la elección de 1994 marcó el primer gran antagonismo entre PSDB y PT.

Palabras-clave: HGPE; el antagonismo; teoría del discurso; PSDB; PT

\section{Résumé}

Le premier antagonisme majeur entre le PSDB et le PT

L'objectif de cet article est de démontrer la construction antagoniste entre les discours produits par les candidatures du PSDB et du PT, réalisés au cours de I'Horaire gratuit de propagande électorale (HGPE) diffusés à la télévision pendant I'élection présidentielle de 1994, qui a fini par présenter le Plano Real comme le point nodal de ce conflit. À partir de là, nous avons saisi que la dimension de I'antagonisme identifiée dans cet espace de conflit permet aux électeurs d'avoir un plus grand accès à l'information sur les candidatures disputant I'élection à la présidence de la République, à la vue de son caractère déconstructiviste. De ce fait, le retour au passé est justifié pour deux raisons principales: a) ce moment peut être lu comme le premier grand antagonisme entre les partis PSDB et PT; b) les études concernant le HGPE n'ont prêté aucune ou peu d'attention à la dimension antagoniste, ce qui peut mettre en lumière un aspect de plus à propos de la décision du vote de la part de l'électeur. Pour cela, on utilisera les aspects théoriques et méthodologiques de la théorie du discours de Laclau et de Mouffe, en insistant sur les concepts de discours et d'antagonisme, indispensables pour saisir les sens discursifs ici démontrés. Nous concluons donc que les élections de 1994 ont été le premier antagonisme majeur entre le PSDB et le PT.

Mots-clés: HGPE; antagonisme; théorie du discours; PSDB; PT

Artigo submetido à publicação em 25 de abril de 2018. Versão final aprovada em 28 de novembro de 2018.

Opinião Pública adota a licença Creative Commons CC-BY.

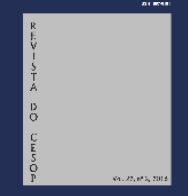

